

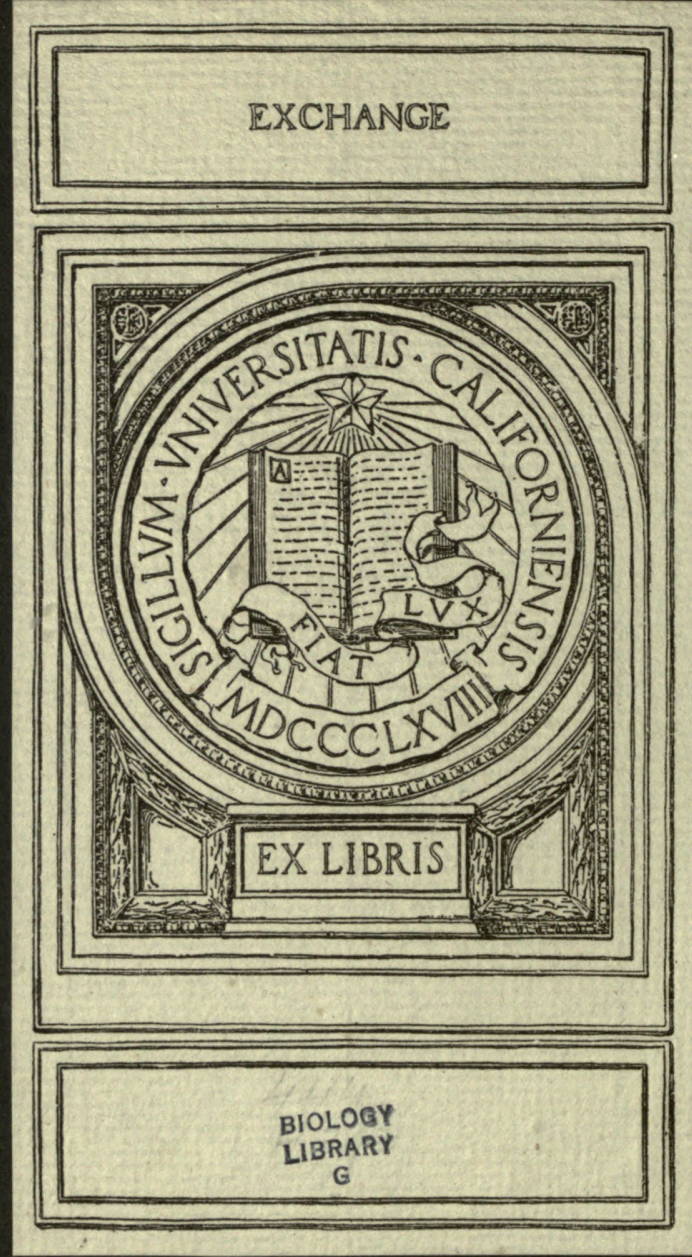




\title{
The Influence of Calcium, Magnesium and Potassium Nitrates upon the Toxicity of Certain Heavy Metals Toward Fungus Spores
}

\section{DISSERTA'TION}

Submitted to the Board of University Studies of the Johns Hopkins University in conformity with the requirements for the degree of Doctor of Philosophy

\author{
By \\ LON A. HAWKINS
}

Baltimore, June, 1913 



\title{
The Influence of Calcium, Magnesium and Potassium Nitrates upon the Toxicity of Certain Heavy Metals Toward Fungus Spores
}

\section{DISSERTATION}

Submitted to the Board of University Studies of the Johns Hopkins University in conformity with the requirements for the degree of Doctor of Philosophy

\author{
$\mathrm{By}$ \\ Lon A. Hawkins
}

Baltimore, June, 1913 



\title{
THE INFLUENCE OF CALCIUM, MAGNESIUM AND POTASSIUM NITRATES UPON THE TOXICITY OF CERTAIN HEAVY METALS TOWARD FUNGUS SPORES. ${ }^{1}$
}

\author{
Lon A. Haw Kins.
}

\begin{abstract}
. ${ }^{2}$
This study has to do with the influence of one salt in altering the toxic effect of another upon fungus spores. It is shown that the toxic effect of copper nitrate on the germination of Gloeosporium spores can be inhibited or modified by the addition to the medium of calcium nitrate and that the molecular ratio of the quantity of the calcium salt thus required to the amount of copper nitrate present increases with the concentration of the latter. This effect is apparently the result of a simultaneous action of the two salts upon the organism and cannot, in the cases here considered, be related either to formation of an undissociated double salt or to depression of the ionization of the toxic salt because of the ion common to the two salts. Potassium nitrate is also effective in inhibiting or modifying the toxicity of copper nitrate. The influence of calcium upon the toxicity of copper is of interest in connection with the problem of fungicides and fungicidal action.

The toxicity of lead nitrate is similarly influenced by the presence of calcium nitrate, and the molecular proportions in which these two salts may be combined so as just to counteract the toxicity of the former were found to be the same for the three different concentrations of lead nitrate that were employed. The toxicity of this lead salt is likewise influenced by proper concentrations of magnesium nitrate. Both calcium nitrate and magnesium nitrate markedly decrease the toxicity of zinc nitrate, but neither exhibits any effect on the toxicity of aluminum nitrate in the concentrations used in these experiments.

The effects produced by the various single salts upon the germinating spores are of interest. Four types of response to the salt solution are clearly discernible. (I) The effect of the solution may be the same as that of distilled water, the spores germinating normally, with long, narrow tubes. (2) A somewhat higher concentration of the toxic substance may

\footnotetext{
${ }^{2}$ The manuscript of this paper was received April r, r9r3. This abstract was preprinted, without change, from these types and was issued as Physiological Researches Preliminary Abstracts vol. $\mathbf{r}$, no.
}

${ }^{1}$ Botanical contribution from the Johns Hopkins University No. 31 . 2, August, ror 3.
\end{abstract}


allow germination, this being abnormal, however, with the production of unusual and characteristic structures. (3) Germination may be inhibited for eighteen hours, the spores germinating when subsequently transferred from the toxic solution to distilled water. (4) The spores may be killed in eighteen hours and thus be incapable of renewed activity even when transferred to water. It was usually possible to bring about these four types of response by means of any one of the compounds used in this study by a proper choice of concentration. An arrangement of these substances in the order of their toxicity, as evidenced by the inhibition of spore germination, is found to hold also for their effectiveness in bringing about the other and less final changes which lead to abnormal growth. A list of the substances employed, arranged in the order of their toxicity follows: $\mathrm{Cu}\left(\mathrm{NO}_{3}\right)_{2}, \mathrm{CuSO}_{4}, \mathrm{~Pb}\left(\mathrm{NO}_{3}\right)_{2}, \mathrm{Al}\left(\mathrm{NO}_{3}\right)_{3}, \mathrm{HNO}_{3}, \mathrm{Zn}\left(\mathrm{NO}_{3}\right)_{2}, \mathrm{Ni}\left(\mathrm{NO}_{3}\right)_{2}$, $\mathrm{Mg}\left(\mathrm{NO}_{3}\right)_{2}, \mathrm{Ca}\left(\mathrm{NO}_{3}\right)_{2}, \mathrm{KNO}_{3}$, sucrose.

It is shown that no one of the several hypotheses heretofore proposed to account for the dynamics of the antagonistic salt action is adequate to explain all the facts brought out in this study:

\section{INTRODUCTION.}

Numerous instances have been recorded of the influence of salts on the toxicity exerted by various substances upon organisms. This antagonistic action, as it is frequently called, of a salt upon a toxic substance, is of considerable importance in influencing the behavior of organisms in a given environment, or indeed in determining whether or not they may exist at all in certain environments. For example, Loew $^{3}$ has shown that the toxic effect on Spirogyra of a one per cent. solution of magnesium nitrate is inhibited by the presence in the medium of a 0.3 per cent. solution of calcium nitrate, while $\mathrm{Loeb}^{4}$ has demonstrated that the addition of a small quantity of a calcium salt to a $0.625 \mathrm{~m}$ solution of $\mathrm{NaCl}$ inhibits the toxic effect of the $\mathrm{NaCl}$ on the development of Fundulus eggs. Osterhout $^{\mathbf{5}}$ has shown that a physiologically balanced solution, containing sodium chloride, magnesium chloride, magnesium sulphate, potassium chloride and calcium chloride, is necessary for the best growth of certain marine algae. True and Bartlett ${ }^{\text {B }}$ have brought out the fact that a ratio of one molecule of calcium to nine molecules of magnesium inhibits the toxic effect of rather high concentrations of magnesium upon roots of Canada field

${ }^{3}$ Loew, O., Ueber die physiologischen Functionen der Calcium- und Magnesium-salze im Pflanzenorganismus. Flora $75: 368-394$. 1892 .

${ }^{4}$ Loeb, J., Ueber den Einflus der Werthigkeit, und möglicherweise der elektrischen Ladung von Ionen auf ihre antitoxische Wirkung. Archiv ges. Physiol. 88: 68-78. 1902.

${ }^{5}$ Osterhout, W. J. V., On the importance of physiologically balanced solutions for plants. I. Marine plants. Bot. Gaz. 42: I27-I34. I906.

True, R. H., and Bartlett, H.H., Absorption and excretion of salts as influenced by concentration and composition of culture solutions. U.S. Dept. Agric. Bur. Plant. Ind. Bulletin 23 I. I9I2. 
peas. Other cases of antagonistic salt action in combinations of salts of the alkali metals or of the alkaline earths have been demonstrated, and some information has been obtained regarding the influence of these salts on the effect of the heavy metals, which seem to be universally toxic. The latter have not received much attention, however, and it seemed worth while to investigate some of these, alone and in the presence of calcium and magnesium, to obtain evidence as to whether the lighter metals may modify in any way the toxicity of the heavy ones. The investigation described in this paper was accordingly undertaken. The problem here involved will be taken up more in detail after some of the literature pertinent to the subject has been considered.

One of the earlier studies of the influence of chemical compounds upon the toxicity of the heavy metals was carried out by Krönig and Paul. ${ }^{7}$ These authors determined the effects of various heavy metals in combination with many salts as well as with certain acids and bases. Mainly from work with Bacillus anthracis, they regard the influence of other halogen compounds upon the toxicity of mercuric chloride as probably due to a depression of the ionization of the latter salt. In this connection they say (page Iro): "Die Desinfectionswirkung wässeriger Mercurichloridlösungen werden durch Zusatz von Halogenverbindungen der Metalle und von Salzäure herabgesetzt. Es ist wahrscheinlich, dass diese Verminderung der Desinfectionskraft auf einer Rückdrängung der elektrolytischen Dissociation beruht."

Clark $^{8}$ carefully studied the influence of various concentrations of sodium chloride upon the toxicity of mercuric chloride as regards the process of germination in various fungus spores and seeds and that of growth in yeasts and bacteria. He found that the toxicity of a mercuric chloride solution increased with addition of small quantities of sodium chloride but decreased when high concentrations of the sodium salt were used. He explained these phenomena by considering that a double salt of sodium chloride and mercuric chloride was formed, such as $\mathrm{Na}_{2} \mathrm{HgCl}_{4}$ or some similar combination. He supposed that the dissociation tension of this double salt was probably much higher than that of mercuric chloride, a consideration which might account for the increased toxicity of combinations in which small amounts of sodium chloride were employed. In this connection, he suggested that the $\mathrm{HgCl}_{4}$ ion present when such a salt as $\mathrm{Na}_{2} \mathrm{HgCl}_{4}$ dissociated at lower concentrations, might be considerably more toxic than the $\mathrm{HgCl}_{2}$ molecule to which he seems to attribute the toxicity of mercuric chloride solution.

\footnotetext{
${ }^{7}$ Krönig, B., and Paul, Th., Die chemischen Grundlagen der Lehre von der Giftwirkung und Desinfection. Zeitsch. Hygiene und Infectionskrankheiten 25: 1-112. 1897.

${ }^{8}$ Clark, J. F., On the toxic value of mercuric chloride and its double salts. Jour. Physic. Chem. 5: $289-3$ I6. 1901.
} 
In a later investigation, on the toxicity of copper in combination with various chemical compounds, the same writer ${ }^{9}$ has shown, for spore germination in Oedocephalum albidum and Rhizopus nigricans that ammonium nitrate, sodium sulphate, potassium sulphate, and potassium chloride all markedly decreased the toxic effects of both copper chloride and copper sulphate. He used relatively high concentrations, in some cases five per cent., of the alkali and ammonium salts. He considers the decreased toxicity just mentioned as probably due to the formation of double salts, as he suggested in the case of mercuric chloride.

Le Renard ${ }^{10}$ studied the comparative toxicities of salts of many of the heavy metals upon Penicillium, the fungus being grown in various concentrations of nutrient media. He used the acetates of potassium, magnesium and ammonium alone, and the acetates, formates, nitrates, phosphates, and sulphates of these three metals with glucose. Also, in combination with various concentrations of the salts in the nutrient medium he used several concentrations of the chlorides and nitrates of zinc, nickel, cobalt and copper, mercuric chloride, silver nitrate, and the sulphate and acetate of copper. The presence in the nutrient medium of the lighter metals in higher concentration was usually found to decrease the toxicity of the heavy metals.

True and Gies ${ }^{11}$ showed that calcium modified the toxicity of various copper salts, of zinc sulphate and of mercuric chloride, in their effect upon the growth of roots of Lupinus albus. In discussing their results these authors say: "The stimulating action of the calcium seems to have operated against the retarding action of the copper, and the result is a marked diminution in the poisonous action of the copper." They thus relate this influence of calcium upon copper to a mutual effect of the two salts on the protoplasm.

Szücs ${ }^{12}$ has recently shown that the toxic effect of copper sulphate on the roots of Cucurbita pepo may be inhibited by aluminum chloride in certain concentrations. In this case he used as index of toxicity the ability of the root to react to a geotropic stimulus after it had been removed from the poisonous solution. He varied the presentation time of the toxic stimulus (solution of copper sulphate) both alone and with addition of aluminum chloride, and found, for the shorter time periods, that the presence of aluminum inhibited the poisonous action of copper. However, when such

\footnotetext{
${ }^{\circ}$ Clark, J.F., On the toxic properties of some copper compounds with special reference to Bordeaux mixture. Bot. Gaz. 33: 26-48. 1902 .

${ }^{10}$ Le Renard, Alf., Influence du milieu sur la résistance du Pénicille crustacé aux substances toxiques. Ann. Sci. Nat. Bot. IX. 16: 276-336. 1912.

11 True, Rodney, H., and Gies, W. J., On the physiological action of some of the heavy metals in mixed solutions. Bull. Tórr. Bot. Club 30: 390-402. 1903 .

${ }^{12}$ Szücs, Joseph, Experimentelle Beiträge zu einer Theorie der antagonistischen Ionenwirkungen. Jahrb. wiss. Bot. 52: 85-143. I9I2.
} 
a combination of the two salts was allowed to act for longer periods, it also was toxic in many cases, and the roots lost their ability to respond afterwards to the geotropic stimulus. He used concentrations of copper sulphate varying from $0.001875 \mathrm{n}$ to $0.075 \mathrm{n}$, combined with aluminum chloride in concentrations varying from $0.005^{n}$ to $0.45 n$. The presentation time of the toxic stimulus ranged from 33 minutes to 26 hours and 50 minutes. This writer also studied the effect upon Spirogyra of quinine hydrochloride, methyl violet and piperidine in combination with various other substances. The toxicity of quinine hydrochloride was altered by various concentrations of other substances, being almost inhibited by aluminum nitrate, markedly decreased by calcium nitrate, and only slightly lessened by potassium nitrate. Thus, the effectiveness of these salts in reducing the toxicity of quinine hydrochloride diminished with the valency of the cation. Similar results were obtained with the same series of salts in combination with methyl violet. The effect of combinations of various substances with piperidine was, in most cases, markedly to increase its toxicity. Szïics apparently considers the antagonistic action, as investigated by him, to be due to the lowering of the rate of absorption of the toxic ion by the presence in the solution of another ion of similar sign. He concludes, in summarizing: “Die Ursache der ' antagonistischen Ionenwirkungen' liegt in allen von mir untersuchten Fällen in der gegenseitigen Beeinflussung der Aufnahmegeschwindigkeit zweier im gleichen Sinne geladener Ionen."

From the results obtained in the investigations just considered, it is apparent that the toxic effect of the heavy metals on an organism can be modified, in some cases at least, by the addition of certain salts in proper concentration. True and Gies, and Szücs, working with higher plants, attribute this influence of one salt on the effect of another to a simultaneous action of the two salts upon the organism itself, while Clark, working with fungi, relates the inhibition of the toxic effect of heavy metals in combination, to some modification of the salts in the solution. The proportions of salts used in the investigations just mentioned were widely different, and it is of course possible that the different conclusions reached may have-been due to this feature. Furthermore, as fungi and higher plants so frequently react differently to the same stimulus, it is possible that one of these two explanations might hold for one group of organisms and the other for the other group. The present study, in which a fungus was employed, was undertaken partly to throw light on the question just suggested.

It was the purpose of this research to examine the effects of the nitrates of copper, lead, zinc, nickel, and aluminum, upon the germination of fungus spores, the salts of these heavy metals being used both alone and in combination with the nitrates of calcium and magnesium, to see whether 
the presence of the lighter metals in various concentrations might or might not decrease the toxic effect of the heavy ones. It was also considered worth while, when such a decrease was found to occur, to determine as far as possible whether this influence might be related to a direct effect of salts on each other in the solution or to some modification of the organism itself. Furthermore the results obtained in these experiments should throw some light on the problem of the comparative toxicity of the various substances here employed, when used alone, and thus upon the general physiological problem of toxicity.

The investigation was carried out at the Laboratory of Plant Physiology of the Johns Hopkins University, and the writer's sincere thanks are due to Professor Burton E. Livingston for his many helpful suggestions and valued assistance throughout the progress of the work.

\section{ORGANISM.}

The fungus spores used in this research were of the Gloeosporium or conidial stage of Glomerella cingulata (Stonem.) S. and v. S., the fungus causing the disease of the apple known as "bitter rot." Not only is the fungus parasitic upon the apple, but according to Shear and Wood, ${ }^{13}$ it is also the cause of disease on other plants. On the apple fruit it produces brown, sunken areas, usually nearly circular in shape, which may be covered with the fruiting bodies of the fungus, the conidia being borne in acervuli. In mass, the spores appear orange-colored but have a hyaline appearance under the microscope. They are usually ovate or oblong in shape, the two diameters being $12-16 \mu$ and $4-6 \mu$. Shear and Wood have shown that certain strains of this fungus, when grown on proper artificial media, may produce conidia for generation after generation, without the interpolation of the ascogenous form at any time. Cultures of such a strain were secured from Dr. Shear for these experiments, and conidia only were produced throughout the investigation, which lasted about eighteen months, though forty or more generations must have passed.

Corn meal agar was used as a medium for the stock cultures. This was prepared by adding 4 teaspoonsful of white corn meal to one litre of distilled water, which was then allowed to stand at about $58^{\circ} \mathrm{C}$. for one hour. After filtration, $12.5 \mathrm{~g}$. of agar flour was added to the infusion, and the mixture was steamed for one and one-half hours. It was then re-filtered and was ready to tube and sterilize. The tubes were slanted and the stock cultures were inoculated in streaks. On this medium the fungus produces but little mycelium, at or beneath the surface, and the conidia are borne in relatively large, orange-colored masses on the surface

${ }^{13}$ Shear, C. L., and Wood, Anna K., Studies of fungus parasites belonging to the genus Glomerella. U.S. Dept. Agric. Bur. Plant Ind. Bulletin 252. 1913. 
of the medium along the streak. The acervuli are visibte in from two to five days after inoculation.

Before the spores were used in the experiments, the stock cultures were allowed to grow undisturbed from ten to fifteen days, a procedure which insured a sufficient quantity of spores from a single tube for the inoculation of an entire series of experimental cultures. Preliminary tests indicated that spores from acervuli in the same tube, but of different ages, were not at all uniform in viability. Direct inoculation of the culture dishes from the spore masses of the stock tubes was thus shown to be unsatisfactory, since it was not only desirable that all cultures contain approximately the same number of spores, but also that the percentage of viability of the spores in all cultures should be as nearly alike as possible. It also seemed desirable to avoid small pieces of agar and bits of mycelium in the liquid cultures, for such contamination might influence the effect of the salts in the solutions on the germination of the spores, as by absorption or the formation of new chemical compounds. The plan was therefore evolved of allowing the stock cultures to grow for from ten to fifteen days, after which period the spore masses were carefully removed, with a platinum needle, to a clean area on the agar surface, from which, after thorough mixing in a little heap, the inoculations to the water cultures were made. This method usually resulted in satisfactory uniformity in the germination of the spores in the various controls, from which fact it was concluded that all cultures thus made contained an approximately equal number of viable spores, and that any inhibition or modification of germination must be due to properties of the culture mediuni rather than to differences in the spores introduced.

In comparing the effect of the various media upon the spores, the main criterion was the presence or absence of germination after a period of eighteen hours. In many cases, however, germination was more or less modified, as in the production of swollen tubes and other abnormalities, and such modifications of germinal activity needed frequently to be taken into account. As has been indicated, it was seldom necessary to consider the percentage of normal germination which occurred, but in many cases the proportion of abnormal to normal growth was approximately determined.

These Gloeosporium spores possess several very favorable features for such an investigation as the present. They are readily wetted by water and aqueous solutions and, being slightly heavier than water, they sink quickly to the bottom of a hanging drop. They germinate readily in distilled water in from three to four hours and produce long filaments in eighteen hours, a feature which is of considerable advantage here, for it is quite conceivable that the influence of various chemical compounds on 
each other and on the germinating spores might be considerably altered if nutrient salts were present in the solution. In view of these considerations these experiments were carried out without the use of nutrient media.

\section{METHODS.}

The salts used in these experiments were "Baker's analysed" chemicals, procured in the original packages. Stock solutions of the different salts, from which the experimental solutions were afterwards prepared, were made up in $0.2 \mathrm{~m}^{14} 0.5 \mathrm{~m}$, or molecular concentration. In preparing the stock solutions the salts were weighed in glass-stoppered weighing bottles directly from freshly opened packages and were dissolved in volumetric flasks. These solutions were then made up to the required volume at a temperature of $15^{\circ} \mathrm{C}$. They were stored in Jena glass bottles which had been carefully washed with saturated solution of potassium dichromate in sulphuric acid, steamed for half a day, again washed with distilled water and finally allowed to soak in distilled water for a month or more, to remove any soluble matter which might be present. Distilled water from a still with tin lined boiler and condenser was used in making the stock solutions as well as in diluting them for the cultural work. Preliminary tests showed that the spores germinated as well in water from this still as in more nearly pure water distilled from potassium permanganate solution, using a hard glass flask and a block tin condenser.

The stock salt solutions were diluted to the concentrations required in making up the solutions for the experiments, by pipetting out the proper amount into a hard glass beaker and then adding the necessary distilled water from a burette. The concentrations of these solutions were so calculated that the culture solutions could be prepared without the measurement of less than $0.5 \mathrm{cc}$. in any case. Thus, errors that might have arisen in attempting to read hundredths of a cubic centimeter on a burette graduated only to tenths, were obviated.

In making up a series of cultures, the two salt solutions which were to be combined were separately diluted to twice the concentration finally desired, and were then placed in burettes. From these were prepared, with addition of water as needed, the combinations and concentrations actually used in the experiments. These mixtures, in volumes of ro $\mathrm{cc}$. or more, were made in small flasks (of about 75 cc. capacity), a flask being provided for each of the different combinations as well as one for the control. The latter solution usually contained the salt of the heavy metal alone.

From each of the flasks just mentioned a small portion of solution (about

\footnotetext{
${ }^{14}$ The letter $m$ is used throughout this paper to denote molecular, a concentration of a single gram molecule in a liter of solution. There seems to be considerable confusion in this important matter of defining solutions, some chemists employing the letter $n$ to denote molecular, although the latter has long been used to denote chemically equivalent.
} 
a cubic centimeter $)$ was placed in a separate glass cylinder $(2 \mathrm{~cm}$. high and $3 \mathrm{~cm}$. in diameter), to which spores from a stock culture were then transferred. These inoculations were made in order, beginning with the weakest solution of the lighter metal. A platinum needle was used for this purpose, flamed and washed to sterilize and clean it after each inoculation.

In each case the tip of the needle was dipped a single time in the well mixed mass of spores which had been prepared on the agar surface, as already described, and the spores that adhered were washed off in the culture solution. Thus, approximately the same number of spores were inoculated into all of the glass dishes and the solutions were then ready for the preparation of the hanging drops.

The drop cultures were made after much the same method as that described by Clark. ${ }^{15}$ Van Tieghem cells were used, small cylinders of glass tubing, with ground ends, $9 \mathrm{~mm}$. high and $12 \mathrm{~mm}$. in diameter, which were cemented to ordinary microscope slides by means of beeswax. Two cells were affixed to each slide. The culture solutions in the glass dishes, into which spores had already been inoculated, were thoroughly mixed with a glass rod. By means of this rod, a drop of the liquid was then placed upon a flamed cover glass.

A small drop of the culture solution from the corresponding flask without spores was placed in the bottom of the Van Tieghem cell and the cover bearing the drop culture was inverted over it. Duplicate drop cultures were made from each concentration of solution, both cultures being placed on the same slide. As has been shown by Clark, the presence at the bottom of the culture cell of a small amount of the same solution as that from which the hanging drop is composed prevents evaporation from the drop and hence obviates marked alteration in its concentration, even if the cultures remain in the thermostat for a considerable time. Without this precaution the solution contained in the hanging drop is apt to become markedly more concentrated during the period of an experiment, which might lead to erratic results. The covers were sealed in position with petrolatum. It was not found necessary to take the precaution recommended by Clark, of first allowing the expanding air to escape through a small opening in the seal, possibly because the temperature of the thermostat here used was only a little above the temperature at which the preparations were made.

For ease in handling the cultures, the slides were placed in sheet metal trays, which could be piled one upon another in the thermostat so as to form a rack. These trays were $15 \mathrm{~cm}$. wide and $20 \mathrm{~cm}$. long, with vertical

${ }^{15}$ Clark, J. F., On the toxic effect of deleterious agents on the germination and development of certain filamentous fungi. Bot. Gaz. 28: $289-327,378-404$. 1890 . 
flanges at the ends, the flanges extending upward about $1.3 \mathrm{~cm}$. and downward about $0.4 \mathrm{~cm}$. They were so bent that the lower flanges of one tray fitted outside the upper flanges of the next lower one, and many trays could thus be arranged in a compact and rigid pile without any disturbance to the slides. The bottom of each tray was perforated with circular openings about $1.5 \mathrm{~cm}$. in diameter and $0.5 \mathrm{~cm}$. apart, to facilitate circulation of air. Each tray carried fourteen slides. The slides were always transferred to and from the thermostat by means of the trays, a whole series of cultures being thus moved together.

The cultures were kept during germination in an electrically heated and automatically regulated thermostat, in which the temperature was maintained at or near $25^{\circ} \mathrm{C}$. As the temperature of the room in which the thermostat was placed sometimes rose above $25^{\circ}$, it was necessary to install apparatus for absorbing heat at such times. To accomplish this, several coils of thin-walled copper tubing carrying a continuous stream of tap water were placed at the top of the thermostat, surrounding a small motor-driven fan, the latter insuring air circulation. The air of the chamber then tended to assume a temperature several degrees below that of the laboratory, and the thermostat acted as though standing in a cold room.

\section{EXPERIMENTATION,}

In these studies, any renewed activity in the protoplasm of the spore was considered as germination. Several forms of such renewed activity are exhibited by the conidia here employed. Without any alteration in size or shape, a portion of the spore may become nearly or quite opaque, thus appearing dark brown or black by transmitted light. A papilla may be formed at any point on the surface. Such papillae may or may not enlarge to form rounded bodies, and may either remain hyaline or become apparently darkened. Papillae may enlarge to form irregularly shaped bodies or may extend outward as markedly thickened tubes. Lastly, the growing papillae may take the form of slender tubes. The latter type of germination always occurs in distilled water and the tubes attain, in a period of eighteen hours, a length at least twice as great as that of the spore itself. In the following treatment germination will be considered "normal" wherever tubes of the last mentioned type, at least twice the length of the spore, were produced in eighteen hours.

In the present section will be considered the various effects upon germination brought about in the presence of the following salts either alone or in certain combinations:
$\mathrm{Ca}\left(\mathrm{NO}_{3}\right)_{2}$
$\mathrm{Pb}\left(\mathrm{NO}_{3}\right)_{2}$
$\mathrm{Ni}\left(\mathrm{NO}_{3}\right)_{2}$
$\mathrm{Mg}\left(\mathrm{NO}_{3}\right)_{2}$
$\mathrm{Zn}\left(\mathrm{NO}_{3}\right)_{2}$
$\mathrm{Cu}\left(\mathrm{NO}_{3}\right)_{2}$
$\mathrm{KNO}_{3}$
$\mathrm{Al}\left(\mathrm{NO}_{3}\right)_{3}$
$\mathrm{CuSO}_{4}$ 


\section{TOXICITY OF SALT COABINATIONS}

\section{Calcium, Magnesium and Potassium.}

It requires a relatively high concentration of calcium, magnesium or potassium nitrate to inhibit the germination of these spores. With $\mathrm{Ca}\left(\mathrm{NO}_{3}\right)_{2}$ normal germination was found in the $0.5 \mathrm{~m}$ solution and swollen tubes were abundant in $0.6 \mathrm{~m}$. At a concentration of $0.7 \mathrm{~m}$, however, none of the spores germinated in any of the four series of duplicate cultures which were carried out. The concentration of this salt which just prevents germination appears, therefore, to lie between $0.6 \mathrm{~m}$ and $0.7 \mathrm{~m}$. Magnesium nitrate is similar to that of calcium in its effect. With this salt the spores germinated normally at a concentration of $0.4 \mathrm{~m}$, and local swellings of the spore wall and swollen tubes were produced in $0.5 \mathrm{~m}$ solution, while no germination was evident when a $0.6 \mathrm{~m}$ concentration was employed. The concentration at which $\mathrm{Mg}\left(\mathrm{NO}_{3}\right)_{2}$ just inhibited germination thus seems to lie between $0.5 \mathrm{~m}$ and $0.6 \mathrm{~m}$. In solutions of $\mathrm{KNO}_{3}$ the spores germinated normally with a concentration of $0.9 \mathrm{~m}$ and formed local swellings of the spore wall with molecular concentration. As the latter was the highest concentration here used, the point at which $\mathrm{KNO}_{3}$ inhibits germination was not determined.

The exceedingly high ,concentrations of these salts, which were found necessary to inhibit germination, made it seem possible that they might be without toxic effect upon the spores; the inhibition of germination which was observed in high concentrations might have been the result of the ligh osmotic pressure exerted by the medium. To obtain evidence on this point the germination of the spores was tested in cane sugar

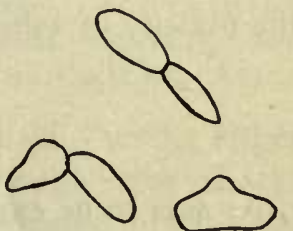

Fig. I. Germinating spores from $1.6 \mathrm{~m}$ sucrose solution, $x$ 650. solution at various concentrations. A $0.2 \mathrm{~m}$ stock solution was prepared from granulated sugar which had been previously pulverized and desiccated; the different concentrations used in the cultures were prepared from this. The spores germinated normally in concentrations of cane sugar up to and including $1.4 \mathrm{~m}$, considerable germination in the form of local swellings (shown in fig. $\mathrm{r}$ ) was found in the $1.6 \mathrm{~m}$ solution, and no germination occurred with $\mathrm{I} .8 \mathrm{~m}$ concentration. The concentration of cane sugar which just inhibits germination lies then between $1.6 \mathrm{~m}$ and $1.8 \mathrm{~m}$.

It will be observed that a $1.6 \mathrm{~m}$ solution of sucrose has about the same effect upon the germination of these Gloeosporium spores as do $0.6 \mathrm{~m}, 0.5 \mathrm{~m}$ and molecular solutions of calcium, magnesium and potassium nitrates 
respectively. Calculations ${ }^{16}$ of the osmotic pressures of these four solutions give $51.36,29.13,26.00$ and 39.31 atmospheres, respectively, from which numbers it becomes obvious that the osmotic concentration of the sugar solution was much greater than that of the other three. It is therefore suggested that, unless the wall and protoplasm of the spores here employed be readily permeable to cane sugar (which seems highly improbable), the inhibiting effects observed with the salt solutions are not to be related primarily to their osmotic properties.

The relatively high osmotic pressure existing within the spores here dealt with, as indicated by the data just given, renders it unnecessary to consider osmotic pressure as a factor in bringing about the modifications and inhibitions of germination which are next to be considered; the concentrations of the various salt solutions employed were always far too low to produce any removal of water from the cells. Similarly, the toxicity of calcium, magnesium and potassium nitrates is so very slight as not to require any consideration in connection with the combinations of these salts with those of the heavy metals; in these combinations the salts of the lighter metals have not here been used in concentrations higher than o.rm.

The influence of the nitrates of calcium, magnesium and potassium upon the toxicity of salts of the heavy metals will now receive attention.

\section{Copper.}

As was to be expected, the effect of $\mathrm{Cu}\left(\mathrm{NO}_{3}\right)_{2}$ upon the germination of these spores was found to be widely different from that of $\mathrm{Ca}\left(\mathrm{NO}_{3}\right)_{2}$. No germination was ever found in concentrations of the copper salt alone higher than $0.00006 \mathrm{~m}$, and it was only in an occasional culture that one or two spores were observed producing local swellings with that concentration. Local swellings of the spore walls and swollen tubes were frequently found with $0.00004 \mathrm{~m}$ and with $0.000026 \mathrm{~m}$ concentration, the next lower one which was here used; with $0.00002 \mathrm{~m}$ solution of $\mathrm{Cu}\left(\mathrm{NO}_{3}\right)_{2}$ germination was about as in distilled water.

Copper nitrate was combined with $\mathrm{Ca}\left(\mathrm{NO}_{3}\right)_{2}$, at several concentrations of the copper salt well above that at which the latter was non-toxic when used alone. In a series of combinations of o.ooorm $\mathrm{Cu}\left(\mathrm{NO}_{3}\right)_{2}$ with dif-

\footnotetext{
${ }^{16}$ Morse, H. N., and Holland, W. W., The osmotic pressure of cane sugar solutions at $25^{\circ}$. Amer. Chem. Jour. 41: 1-19. 1909. The osmotic pressure of molecular cane sucar was measured directly by these writers and the osmotic pressure of $1.6 \mathrm{~m}$. eane sugar as given above has been calculated from their tables. The result is probably low, for they found that the ratio of observed to calculated osmotic pressure increases with the concentration. For the gas pressure formula, by which the osmotic pressure of the two electrolytes is calculated, see Landolt, H., Börnstein, R., and Meyerhoffer, W., Physikalische* chemische Tabellen, 3 te Auflage. Berlin. i 905 ; page 24.
} 
ferent concentrations of the calcium salt, ranging from $0.00003125 \mathrm{~m}$ to $0.000625 \mathrm{~m}$, the spores germinated readily in those cultures where the concentration of $\mathrm{Ca}\left(\mathrm{NO}_{3}\right)_{2}$ was $0.0000625 \mathrm{~m}$ or higher. With the last named concentration many local swellings were found, and also short swollen tubes (see fig. 2), much as in the $0.00004 \mathrm{~m}$ concentration of $\mathrm{Cu}\left(\mathrm{NO}_{3}\right)_{2}$ alone. With the next lower concentration of the calcium salt, $0.00003125 \mathrm{~m}$, no germination occurred.

From these facts it appears that the toxicity of $0.000 \mathrm{Im} \mathrm{Cu}\left(\mathrm{NO}_{3}\right)_{2}$ solution is so reduced as to be physiologically equivalent to a $0.00004 \mathrm{~m}$ solution of the same salt, by the addition to the former solution of five molecules of $\mathrm{Ca}\left(\mathrm{NO}_{3}\right)_{2}$ for every eight molecules of $\mathrm{Cu}\left(\mathrm{NO}_{3}\right)_{2}$ present. The addition of the lighter metal in this proportion produces the same effect as though the $0.000 \mathrm{Im}$ copper solution had been diluted to two and a half times its original volume.

Copper sulphate exhibits about the same toxicity toward these Gloeosporium spores as does the nitrate. A series of combinations of this salt with $\mathrm{Ca}\left(\mathrm{NO}_{3}\right)_{2}$, quite similar to the series with $\mathrm{Cu}\left(\mathrm{NO}_{3}\right)_{2}$ just described, gave no germination in solutions containing $0.00003125 \mathrm{~m}$ concentrations of the calcium salt, while germination occurred in some of the cultures con-
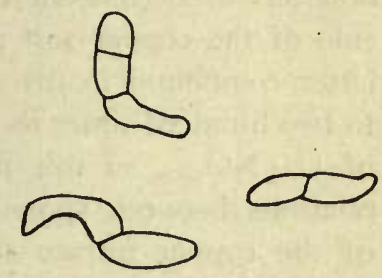

Fig. 2. Germinating spores from combination solution containing $0.00006 \mathrm{~m} \mathrm{Ca}\left(\mathrm{NO}_{3}\right)_{2}$ and $0.000 \mathrm{Im} \mathrm{Cu}\left(\mathrm{NO}_{3}\right)_{2}, \times 65^{\circ}$. taining $0.0000625 \mathrm{~m} \mathrm{Ca}\left(\mathrm{NO}_{3}\right)_{2}$. In general, the effect of $\mathrm{CuSO}_{4}$, either alone or in combination with $\mathrm{Ca}\left(\mathrm{NO}_{3}\right)_{2}$, was practically the same as was that of $\mathrm{Cu}\left(\mathrm{NO}_{3}\right)_{2}$. This furnishes some additional evidence toward the already rather firmly established conclusion, that the toxicity of copper salts is due to the cations, and it also indicates the probability that considerations bearing upon this toxicity need deal only with the cations.

A series of experiments was carried out using $0.0004 \mathrm{~m} \mathrm{Cu}\left(\mathrm{NO}_{3}\right)_{2}$ in combination with concentrations of $\mathrm{Ca}\left(\mathrm{NO}_{3}\right)_{2}$ ranging from $0.00025 \mathrm{~m}$ to $0.025 \mathrm{~m}$. The spores in these combinations germinated readily in the presence of $\mathrm{Ca}\left(\mathrm{NO}_{3}\right)_{2}$ in concentrations ranging from $0.00 \mathrm{Im}$ to $0.025 \mathrm{~m}$, but no germination was found in combinations with $0.0005 \mathrm{~m}$ or $0.00025 \mathrm{~m}$ of the calcium salt. The form and abundance of germination with $0.00 \mathrm{Im}$ $\mathrm{Ca}\left(\mathrm{NO}_{3}\right)_{2}$ was here much the same as that found in $0.00004 \mathrm{~m}$ of the copper salt alone. Here a ratio of five molecules of the calcium salt to two of the copper salt, the latter occurring in the solution at a concentration of $0.0004 \mathrm{~m}$, reduces the toxicity of the $\mathrm{Cu}\left(\mathrm{NO}_{3}\right)_{2}$ so as to produce an effect on spore germination equivalent to that exercised by a $0.00004 \mathrm{~m}$ solution of the copper salt alone. In other words, addition to a $0.0004 \mathrm{~m} \mathrm{Cu}\left(\mathrm{NO}_{3}\right)_{2}$ solution, of $\mathrm{Ca}\left(\mathrm{NO}_{3}\right)_{2}$ in the molecular ratio of five of th: latter to two of 
the copper salt, has the same effect as diluting the $\mathrm{Cu}\left(\mathrm{NO}_{3}\right)_{2}$ solution to ten times its original volume.

A third series of combinations of the same two salts, but with higher concentrations, was carried out in a manner somewhat different from that employed in the preceding series. Here the concentration of $\mathrm{Ca}\left(\mathrm{NO}_{3}\right)_{2}$ was the same $(0.05 \mathrm{~m})$ in all of the cultures, while that of the copper salt varied. The concentrations of $\mathrm{Cu}\left(\mathrm{NO}_{3}\right)_{2}$ ranged from $0.00025 \mathrm{~m}$ to $0.0 \mathrm{Im}$, and the spores germinated in all the concentrations used except the highest. With a concentration of $0.008 \mathrm{~m} \mathrm{Cu}\left(\mathrm{NO}_{3}\right)_{2}$ germination was similar to that found with $0.00004 \mathrm{~m}$ of the copper salt without the addition of $\mathrm{Ca}\left(\mathrm{NO}_{3}\right)_{2}$. From this series it appears that addition to the $\mathrm{Cu}\left(\mathrm{NO}_{3}\right)_{2}$ solution here used $(0.008 \mathrm{~m})$, of about six molecules of $\mathrm{Ca}\left(\mathrm{NO}_{3}\right)_{2}$ for each molecule of the copper salt present in the solution, reduces the toxicity of the latter compound in the same way as though the solution had been diluted to two hundred times its original volume. It appears as though the presence of $\mathrm{Ca}\left(\mathrm{NO}_{3}\right)_{2}$, in this molecular proportion of about 6 to $\mathrm{I}$, altered the relations between spores and solution so that only a two-hundredth part of the copper nitrate actually present was effective to modify or retard the germination processes.

A series of combinations of $\mathrm{Cu}\left(\mathrm{NO}_{3}\right)_{2}$ with $\mathrm{KNO}_{3}$ was carried out, in which a constant concentration of the potassium salt, $0.05 \mathrm{~m}$, was used in combination with $\mathrm{Cu}\left(\mathrm{NO}_{3}\right)_{2}$ in concentrations ranging from $0.0002 \mathrm{~m}$ to o.o Im. The spores germinated in concentrations up to and including $0.002 \mathrm{~m}$ of the copper salt. In the last mentioned concentration, the form of germination was quite similar to that found in a $0.00004 \mathrm{~m}$ solution of the copper salt alone. Thus in a solution containing $\mathrm{KNO}_{3}$ at a $0.05 \mathrm{~m}$ concentration and $\mathrm{Cu}\left(\mathrm{NO}_{3}\right)_{2}$ at a $0.002 \mathrm{~m}$ concentration (a molecular ratio of 25 of the potassium salt to I of the other), the toxicity of the copper salt is decreased to a magnitude only one fiftieth as great as is that shown by this concentration of the copper salt alone.

The results of the three series of combinations of copper nitrate with calcium nitrate which have been described, are summarized in table I, together with certain other data which require consideration.

From the data just given the question arises, whether the influence of calcium nitrate in reducing the toxicity of the copper salt may be due to a direct effect produced in the solution or to some change brought about in the spore itself. Krönig and Paul [97], in considering an effect similar to this, in which the toxicity of $\mathrm{HgCl}_{2}$ upon Bacillus anthracis was decreased by the addition of $\mathrm{NaCl}$, concluded that the change thus brought about is due to depression of the ionization of the salt of the heavy metal. Such a supposition cannot apply in the present case, however; that alteration in the ionization of $\mathrm{Cu}\left(\mathrm{NO}_{3}\right)_{2}$ cannot be the cause 
of the diminution of its toxicity as here observed, is clearly shown by simple calculation according to the isohydric principle. The percentage of dissociation of $\mathrm{Cu}\left(\mathrm{NO}_{3}\right)_{2}$ in the mixtures here employed should be determined by the concentration of the $\mathrm{NO}_{3}$ radical. Following this generalization, the data given in table $\mathrm{I}(\mathrm{C}$, a) have been obtained. Seventy-six per cent. of the copper salt of the first combination is seen to be dissociated.

TABLE I

\begin{tabular}{|c|c|c|c|c|}
\hline & - & $\begin{array}{l}\text { Series } \\
\text { I }\end{array}$ & $\begin{array}{l}\text { Series } \\
\text { II }\end{array}$ & $\begin{array}{l}\text { Series } \\
\text { III }\end{array}$ \\
\hline \multirow{2}{*}{$\begin{array}{l}\text { A. } \mathrm{Cu}\left(\mathrm{NO}_{3}\right)_{2} \text { present in the } \\
\text { medium, molecular... }\end{array}$} & a. Common fraction. . $\because \ldots$ & $1^{\frac{1}{25}}$ & $\frac{1}{2500}$ & $10 \frac{1}{0} \sigma 0$ \\
\hline & b. Decimal fraction...... & 0.008 & 0.0004 & 0.0001 \\
\hline \multirow{3}{*}{$\begin{array}{l}\text { B. } \mathrm{Ca}\left(\mathrm{NO}_{3}\right)_{2} \text { required to al- } \\
\text { low same kind and } \\
\text { amount of germination } \\
\text { as occurs in } 0.00004 \mathrm{~m} \\
(\mathrm{~m} / 25000) \quad \mathrm{Cu}\left(\mathrm{NO}_{3}\right)_{2} \\
\text { without } \mathrm{Ca}\left(\mathrm{NO}_{3}\right)_{2} \ldots \ldots\end{array}$} & $\begin{array}{r}\text { a. Common fraction, mole- } \\
\text { cular................ }\end{array}$ & $\frac{1}{80}$ & $\frac{1}{1000}$ & $\frac{1}{16000}$ \\
\hline & $\begin{array}{r}\text { b. Decimal fraction, mole- } \\
\text { cular.................. }\end{array}$ & 0.05 & $0.00 \mathrm{I}$ & $0.000 \mathrm{I}$ \\
\hline & $\begin{array}{l}\text { c. Number of molecules of } \\
\mathrm{Ca}\left(\mathrm{NO}_{3}\right)_{2} \text { for each } \\
\text { molecule of } \mathrm{Cu}\left(\mathrm{NO}_{3}\right)_{2}\end{array}$ & 6.25 & $2 \cdot 50$ & 0.63 \\
\hline \multirow{2}{*}{$\begin{array}{l}\text { C. Concentration of disso- } \\
\text { ciated } \mathrm{Cu}\left(\mathrm{NO}_{3}\right)_{2} \text { pres- } \\
\text { ent in mixture, mole- } \\
\text { cular.............. }\end{array}$} & $\begin{array}{l}\text { a. According to the isohy- } \\
\text { dric principle........ }\end{array}$ & $0.006 \mathrm{I}$ & 0.0004 & $0.000 \mathrm{I}$ \\
\hline & $\begin{array}{l}\text { b. From potentiometer } \\
\text { measurements....... }\end{array}$ & $0.005^{8}$ & 0.0004 & $0.000 \mathrm{I}$ \\
\hline $\begin{array}{l}\text { D. Concentration of disso- } \\
\text { ciated } \mathrm{Cu}\left(\mathrm{NO}_{3}\right)_{2} \text { in } \\
\text { physiologically equiva- } \\
\text { lent solution of this } \\
\text { salt alone, molecular. }\end{array}$ & $\begin{array}{c}\text { From conductivity meas- } \\
\text { urements (Jones' } \\
\text { tables) } \ldots \ldots \ldots \ldots \ldots\end{array}$ & 0.00004 & 0.00004 & 0.00004 \\
\hline
\end{tabular}

Now, if only one per cent. of the copper here actually present in the mixture were ionized, the concentration of the $\mathrm{Cu}$ ion would correspond to that in an $.0 .00008 \mathrm{~m}$ solution of $\mathrm{Cu}\left(\mathrm{NO}_{3}\right)_{2}$ alone, which, as has been shown, is stronger than is necessary to inhibit spore germination. It is therefore apparent that the decrease in the toxicity of the copper salt shown in these combinations with $\mathrm{Ca}\left(\mathrm{NO}_{3}\right)_{2}$ is not to be related to decreased ionization of $\mathrm{Cu}\left(\mathrm{NO}_{3}\right)_{2}$.

Another theory to account for a similarly decreased toxicity of $\mathrm{HgCl}_{2}$ 
in the presence of $\mathrm{NaCl}$ was advanced by Clark [OI], who considered that a double salt was formed, such as $\mathrm{Na}_{2} \mathrm{HgCl}_{4}$, and supposed this to be only slightly dissociated in the presence of an excess of $\mathrm{NaCl}$. This writer also worked with various copper salts in the presence of $\mathrm{KNO}_{3}, \mathrm{~K}_{2} \mathrm{SO}_{4}$, $\mathrm{NH}_{2} \mathrm{SO}_{4}$, etc., and suggested that the decreased toxicity of the copper salts, which was uniformly observed in such combinations, was likewise due to formation of double salts.

In view of the work of Hosford and Jones, ${ }^{17}$ on the dissociation of double salts in dilute solution, it seems very improbable that the lowering of the toxicity of $\mathrm{Cu}\left(\mathrm{NO}_{3}\right)_{2}$ brought about by $\mathrm{Ca}\left(\mathrm{NO}_{3}\right)_{2}$, as shown in the present study, is due to decreased ionization of the toxic compound, brought about by double salt formation. It is, however, possible to obtain direct evidence on this question by comparing the concentrations of copper ions in the various solutions, with and without the calcium salt. The percentage of dissociation occurring in simple solutions of $\mathrm{Cu}\left(\mathrm{NO}_{3}\right)_{2}$ has been determined experimentally for many concentrations, and these data are available in published tables. ${ }^{18}$ From such data may be derived the concentration of copper ions present in any solution containing only $\mathrm{Cu}\left(\mathrm{NO}_{3}\right)_{2}$, but no published data are yet available from which might be ascertained the concentrations of copper ions in the binary mixtures here dealt with.

The determinations here required of the relative concentrations of copper ions in solutions of $\mathrm{Cu}\left(\mathrm{NO}_{3}\right)_{2}$ with and without addition of the calcium salt, may be made by means of the potentiometer. ${ }^{10}$ With this instrument the solutions involved in table I were tested, and the differences in electrical potential between the combination solutions of $\mathrm{Cu}\left(\mathrm{NO}_{3}\right)_{2}$ and $\mathrm{Ca}\left(\mathrm{NO}_{3}\right)_{2}$ and the corresponding simple solutions of $\mathrm{Cu}\left(\mathrm{NO}_{3}\right)_{2}$ were measured. The two solutions to be tested (for example, the simple solution containing $0.008 \mathrm{~m} \mathrm{Cu}\left(\mathrm{NO}_{3}\right)_{2}$ and the combination solution containing

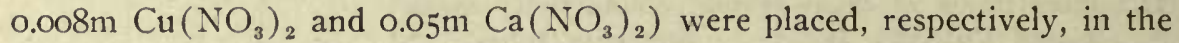
two arms of a U-tube, separated below by a saturated solution of ammonium nitrate. Into each arm of the U-tube was introduced a copper electrode and these were connected with a potentiometer (Leeds and Northrup, type $\mathrm{K})$. The potentiometer was so calibrated that the difference in voltage between the two copper solutions might be read directly on the instrument.

\footnotetext{
${ }^{17}$ Hosford. H. H., and Jones, Harry C., Conductivity, temperature coefficients of conductivity and dissociation of certain electrolytes. Amer. Chem. Jour. 46:240-278. 1911.

${ }^{18}$ Jones, Harry C., Electrical conductivity, dissociation and temperature coefficients of conductivity, from zero to sixty-five degrees, of aqueous solutions of a number of salts and organic acids. Carnegie Institution of Washington Publ. 170. Washington. I9 12.

${ }^{10}$ Loomis, N. E., and Acree. S. F., A study of the hydrogen electrode, of the calomel electrode, and of contact potential. Amer. Chem. Jour. 46:585-620. $191 \mathrm{r}$.

It is a pleasure to acknowledge here, that the suggestion of this method, as applicable to the problem in hand, is due to Professor S. F. Acree, of the Chemistry Department of the Johns Hopkins University, and that much valuable help in making the determinations was received from him and from Dr. C. N. Myers. This part of the work was carried out at the chemical laboratory.
} 
The copper electrodes were freshly plated and calibrated, for subsequent correction of the readings, with reference to any difference in potential which might exist between them when both were placed in the simple $\mathrm{Cu}\left(\mathrm{NO}_{3}\right)_{2}$ solution.

The difference in concentration of copper inns in the two solutions thus compared was calculated from the observed difference in electrical potential by the following formula:

$$
\mathrm{V}=0.0591 \log _{10} \frac{\mathrm{C}}{\mathrm{C}_{1}}
$$

in which $\mathrm{V}$ is the observed Electromotive force, in volts; $\mathrm{C}$ and $\mathrm{C}_{1}$ are the concentrations, respectively, of the copper ions in the two solutions, and the quantity $0.059 \mathrm{I}$ is a constant (Loomis and Acree [II], page 59I).

In each of the tests with which we are at present concerned three entirely separate determinations were made, for each of which the reading was several times repeated, and the results were in excellent agreement. It was found that the difference in electric potential between the $0.008 \mathrm{~m}$ solution of $\mathrm{Cu}\left(\mathrm{NO}_{3}\right)_{2}$ and the same solution containing also a $0.05 \mathrm{~m}$ concentration of $\mathrm{Ca}\left(\mathrm{NO}_{3}\right)_{2}$, was 0.006 volt, the simple solution having the higher potential. From this observation it appears, by substitution in the formula given above, that

$$
\mathrm{C}_{1}=1.26
$$

or that the concentration of copper ions in the combination solution is $\frac{\mathrm{I}}{\mathrm{I} .26}$, or 0.794 , as great as that in the simple' one. Now, from Jones' [12] conductivity tables (page 57), it is found by interpolation that the $\mathrm{Cu}\left(\mathrm{NO}_{3}\right)_{2}$ in our simple solution $(0.008 \mathrm{~m})$ is about 90.6 per cent. dissociated at $25^{\circ} \mathrm{C}$. It thus appears that the $\mathrm{Cu}\left(\mathrm{NO}_{3}\right)_{2}$ in the combination solution here considered must be dissociated to an extent equal to $0.794 \times$ 90.6, or 7I.9 per cent.

It has been shown above (page $7 \mathrm{I}$ ) that the $\mathrm{Ca}\left(\mathrm{NO}_{3}\right)_{2}$ in this particular combination should decrease the dissociation of the copper salt, on account of the common ion, to 76 per cent. There is thus a difference of about 4 per cent., between the dissociation of the $\mathrm{Cu}\left(\mathrm{NO}_{3}\right)_{2}$ in this mixture as calculated from the isohydric principle and that derived from the potentiometer measurements. This difference may, of course, be due to the formation of a double salt, following the hypothesis of Clark already mentioned, but it makes no difference in the present discussion whether it be 76 or 72 per cent. of the $\mathrm{Cu}\left(\mathrm{NO}_{3}\right)_{2}$ that is here dissociated; as has been stated, the solution would still be toxic enough to inhibit germination in these spores if only one per cent. of the total $\mathrm{Cu}\left(\mathrm{NO}_{3}\right)_{2}$ were dissociated.

The remaining two concentrations of $\mathrm{Cu}\left(\mathrm{NO}_{3}\right)_{2}(0.0004 \mathrm{~m}$ and $0.000 \mathrm{Im}$, PHYSIOLOGICAL RESEARCHES VOL. I, NO. 2, SERIAL NO. 2 ,
AUGUST, I9I3. 
see table I), with and without additional $\mathrm{Ca}\left(\mathrm{NO}_{3}\right)_{2}$, were also subjected to potentiometer determinations of the concentrations of copper ions present therein. In neither case was there any difference in electrical potential between the two corresponding solutions. It is therefore clear that at least 99 per cent. of the $\mathrm{Cu}\left(\mathrm{NO}_{3}\right)_{2}$ is to be considered as dissociated in these solutions, whether the calcium salt be present or not (see table I, C, b).

From the foregoing considerations, it seems quite clear that the influence of $\mathrm{Ca}\left(\mathrm{NO}_{3}\right)_{2}$ in reducing the toxic effect of $\mathrm{Cu}\left(\mathrm{NO}_{3}\right)_{2}$ on the germination of the spores here employed is not at all to be related to any changes brought about in the solution itself by the addition of the calcium salt. It appears that this antitoxic or antagonistic influence must be effective upon the spores themselves, so altering them that they become capable of germination in solutions whose concentration of free copper ions would inhibit this process were it not for the presence of the calcium salt.

Whether the copper enters the spores and exerts its toxic action directly, through some alteration in the protoplasm, or whether this toxic influence is exerted primarily upon the spore walls or upon the surface film of the protoplasm, thus perhaps creating some disturbance in physico-chemical equilibrium that may subsequently be propagated inward, is a question for the answering of which no evidence is yet at hand. Nevertheless, the present studies have clearly demonstrated that the presence of $\mathrm{Cu}\left(\mathrm{NO}_{3}\right)_{2}$ alone in the medium inhibits germination if the concentration be above a very low limit, produces markedly altered forms of renewed activity if the concentration is somewhat lower, and allows normal germination only when the solution is exceedingly dilute. While these facts must be interpreted to mean that the copper salt tends to upset the protoplasmic system in some way and that it is possible for that system to be so disturbed as either to inhibit germination absolutely or to allow this process to proceed in modified form, yet much more direct evidence of such protoplasmic disturbance was frequently met with in the progress of this work. Spores in which all germinational activity had been prevented by the presence of $\mathrm{Cu}\left(\mathrm{NO}_{3}\right)_{2}$ frequently possessed a characteristic, coarsely granular appearance, as though a precipitate or coagulum had been formed within the protoplasm. Furthermore, this same appearance was often encountered in spores which exhibited modified germination under the influence of copper. From this it appears that the granular appearance of the protoplasm does not necessarily denote death, but to settle this point conclusively and to determine whether the production of apparent granulation might not be a post mortem effect, the following experiment was performed.

Spores which had been for eighteen hours in cultures with $0.00008 \mathrm{~m}$ solution of $\mathrm{Cu}\left(\mathrm{NO}_{3}\right)_{2}$ alone were employed. In this solution no germination has ever been found, in the more than twenty separate cultures which 
have been observed, and the protoplasm usually appears markedly granular. The spores were transferred from the poison solution to a new drop culture with distilled water and were then returned to the thermostat. At the end of twenty-four hours, observation showed that many of the granular spores had germinated normally, although the granular appearance was still very noticeable. Further proof that the granulated appearance with which we have here to deal is not a post mortem effect of copper poisoning may be derived from the fact that the germinal tubes of spores which had germinated in a combination solution of $0.000 \mathrm{Im} \mathrm{Cu}\left(\mathrm{NO}_{3}\right)_{2}$ and $0.00006 \mathrm{~m} \mathrm{Ca}\left(\mathrm{NO}_{3}\right)_{2}$ elongated considerably when the cultures were allowed to remain in the thermostat for a second day, although the spores showed the characteristic granulation above mentioned.

It seems probable, from these and other similar lines of evidence, that the copper of the solution penetrates the spore wall and gives rise to the precipitation or coagulation effect just described.

It may be noted here that the influence of calcium upon the toxicity of copper is of interest in connection with the problem of fungicides and fungicidal action. From the results obtained in the experiments described above, the conclusion seems warranted that only a small portion of the soluble copper in Bordeaux mixture is effective as. a fungicide. Yet it is a well known fact that a long list of fungous diseases, including apple bitter-rot, can be controlled by the proper applications of this mixture to the host plants. The use of $\mathrm{KOH}$ instead of $\mathrm{Ca}(\mathrm{OH})_{2}$ in preparing the fungicide should result in a much more toxic mixture, for, as brought out in the preceding experiments, potassium is only about one fourth as effective as calcium in decreasing the toxicity of copper. From the standpoint of the host, however, it is quite probable that this anti-toxic effect of the calcium is important in preventing "spray-injury" to the foliage and fruit, while the small amount of soluble copper present, is, in most cases, sufficient to prevent fungous growth.

\section{Lead.}

The nitrate of lead is considerably less toxic toward the Gloeosporium spores here employed than is that of copper. The concentration just inhibiting germination after eighteen hours was found to be about $0.004 \mathrm{~m}$. With a concentration of $0.002 \mathrm{~m}$ of the lead salt, some of the spores showed slight terminal or lateral swellings. At this concentration spores were frequently found in which one half was brown or blackened while the other seemed devoid of protoplasm, appearing as if the protoplasmic contents had all collected in one end and had then taken on a thicker wall. No increase in size or local swelling was apparent in such cases. In a concentration of $0.00 \mathrm{Im}$ the blackened bodies just mentioned were found, as 
well as swellings, and also definite outgrowths from one or both ends of the spore. The latter (shown in figure 3) are of particular interest and require some attention here. They are spherical in shape, dark brown or black in color and appear in all respects similar to the chlamydospores or appressoria which have been frequently described as resulting under certain conditions, from the germination of spores of various Gloeosporium forms.

Appressoria have been described by Hasselbring ${ }^{20}$ as forming when nutrient materials are absent and when germinating spores or germ tubes come in contact with such hard surfaces as are furnished by the cover glass in a drop culture or by the epidermis of various fruits. This writer considers that they function as holdfasts and that they result from a contact stimulus acting upon spores or tubes which are not well nourished. That such bodies are frequently formed when germ tubes come in contact with the cover glass of a hanging drop culture, has often been demonstrated in the present studies. They are especially characteristic of cultures with certain salt solutions, at concentrations somewhat below that at which

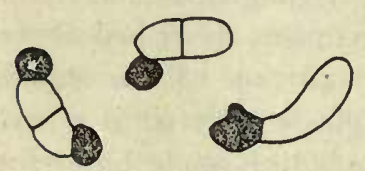

Fig. 3. Germinating spores from $0.00033 \mathrm{~m}$ $\mathrm{Pb}\left(\mathrm{NO}_{3}\right)_{2}, \times 65^{\circ}$. germination is entirely suppressed but above that at which normal development occurs. Here their formation does not appear to be related to any contact stimulus, however. In some cases swollen bodies are produced which have the form of appressoria but which are hyaline like the usual spores and germ-tubes of this fungus, thus apparently differing from the appressoria only in not being brown or black in color. In the descriptions which follow the term appressoria will be used to denote the dark colored, appressorium-like bodies, and swellings of similar form but without dark appearance will be termed hyaline appressoria. These terms are applied here merely in a descriptive way, without intended implication that the bodies thus designated may not be physiologically or otherwise different from the appressoria of the mycologists.

In concentrations of $\mathrm{Pb}\left(\mathrm{NO}_{3}\right)_{2}$ from $0.000 \mathrm{Im}$ to $0.00005 \mathrm{~m}$, most of the germination observed resulted in appressoria. Some of the similar, hyaline swellings also occurred in these cultures. When cultures where appressoria were common were allowed to remain in the thermostat for several days and were examined from time to time, these swellings continued to develop successively from the same spore, until sometimes as many as four appeared together at one end (see fig. 4). In the formation of chains of these bodies it appeared, from the observation of different stages, that a second or later swelling may be brought about either by the germination of one previously formed or by enlargement of the constricted portion of

\footnotetext{
${ }^{20}$ Hasselbring, H., The appressoria of anthracnoses. Bot. Gaz. 42: $135-142$. 1906
} 
the tube between one previously formed and the spore itself; in the latter case possibly by new growth from the spore. In many cases a light colored area quite like that considered by Hasselbring to be a pore, could be distinguished, and this may have been present in all cases. Spores which had germinated in drop cultures by forming appressoria were transferred to new cultures in distilled water and returned to the thermostat. Nearly all the appressoria had germinated with normal germ tubes at the end of twenty-four hours.

An occasional spore germinated normally in a concentration of $0.00005 \mathrm{~m}$ $\mathrm{Pb}\left(\mathrm{NO}_{3}\right)_{2}$, and a few normal tubes were found in the $0.00004 \mathrm{~m}$ concentration, but it was only in the $0.00002 \mathrm{~m}$ concentration that no effect of the $\mathrm{Pb}\left(\mathrm{NO}_{3}\right)_{2}$ upon the germination of the spores was noticeable. In the latter concentration the spores germinated with long tubes, just as in simultaneous controls in distilled water.

Series including combinations of $\mathrm{Pb}$ $\left(\mathrm{NO}_{3}\right)_{2}$ with $\mathrm{Ca}\left(\mathrm{NO}_{3}\right)_{2}$ were carried out at three different concentrations of the lead salt, $0.00016 \mathrm{~m}, 0.00033 \mathrm{~m}$, and $0.00066 \mathrm{~m}$. With a $0.00066 \mathrm{~m}$ concentration of $\mathrm{Pb}-$ $\left(\mathrm{NO}_{3}\right)_{2}$ no concentration of the calcium salt was found which entirely suppressed the formation of appressoria and in which only normal germination was produced, though with a concentration of $0.05 \mathrm{~m} \mathrm{Ca}\left(\mathrm{NO}_{3}\right)_{2}$ only a few appressoria were found. This combination gave practically the same results as were found with a $0.00004 \mathrm{~m}$ con-
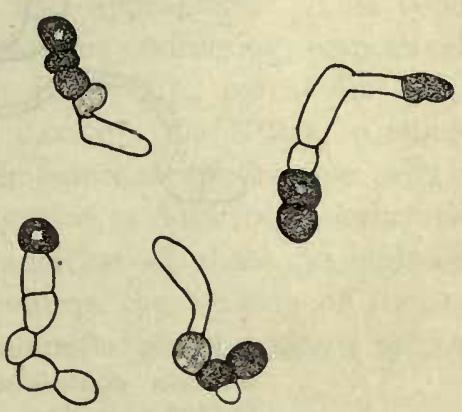

Fig. 4. Spores after four day in $0.004 \mathrm{~m} \mathrm{~Pb}\left(\mathrm{NO}_{3}\right)_{2}, \times 650$. centration of $\mathrm{Pb}\left(\mathrm{NO}_{3}\right)_{2}$ alone; i.e., somewhat over 50 per cent. of the germination was normal, though a considerable number of swellings and appressoria were formed. In the combination of the same concentration of $\mathrm{Pb}\left(\mathrm{NO}_{3}\right)_{2}(0.00066 \mathrm{~m})$ with $0.004 \mathrm{~m}$ of the calcium salt the effect produced was similar to that found in cultures with $0.00005^{\mathrm{m}}$ concentration of $\mathrm{Pb}\left(\mathrm{NO}_{3}\right)_{2}$; only occasional normal tubes were found, these probably constituting less than I per cent. of the total germination. With concentrations of $0.001 \mathrm{~m}, 0.002 \mathrm{~m}$ and $0.003 \mathrm{~m} \mathrm{Ca}\left(\mathrm{NO}_{3}\right)_{2}$, comtined with a $0.00066 \mathrm{~m}$ concentration of the lead salt, practically no normal tubes were produced, germination resulting in appressoria and swellings. These concentrations correspond to solutions of $\mathrm{Pb}\left(\mathrm{NO}_{3}\right)_{2}$ alone varying in concentration from $0.00 \mathrm{Im}$ to $0.000 \mathrm{Im}$.

In the second series of combinations of $\mathrm{Pb}\left(\mathrm{NO}_{3}\right)_{2}$ with $\mathrm{Ca}\left(\mathrm{NO}_{3}\right)_{2}$, the concentration of the first salt was $0.00033 \mathrm{~m}$ and the same concentrations of $\mathrm{Ca}\left(\mathrm{NO}_{3}\right)_{2}$ were employed as in the series just described. The results in 
these experiments were similar to those of the previous series, with some differences due to the lower concentration of the lead salt. Practically no appressoria were formed with the combination containing the $0.05 \mathrm{~m}$ concentration of $\mathrm{Ca}\left(\mathrm{NO}_{3}\right)_{2}$, germination being here (see fig. 5) about the same as that which occurred with the $0.00002 \mathrm{~m}$ concentration of the lead salt alone. With a combination containing o.orm $\mathrm{Ca}\left(\mathrm{NO}_{3}\right)_{2}$, the same effect was obtained as with $0.00004 \mathrm{~m}^{\mathrm{Pb}}\left(\mathrm{NO}_{3}\right)_{2}$ alone, and with combination containing $0.002 \mathrm{~m} \mathrm{Ca}\left(\mathrm{NO}_{3}\right)_{2}$ about the same effect was evident as with a concentration of $0.00005 \mathrm{~m} \mathrm{~Pb}\left(\mathrm{NO}_{3}\right)_{2}$ alone. In the combinations with $0.00 \mathrm{Im}$ and $0.0005 \mathrm{~m} \mathrm{Ca}\left(\mathrm{NO}_{3}\right)_{2}$ the results were practically the same as with a concentration of $0.000 \mathrm{Im} \mathrm{Pb}\left(\mathrm{NO}_{3}\right)_{2}$ alone; most of the germination here gave appressoria.

With a $0.00016 \mathrm{~m}$ concentration of $\mathrm{Pb}\left(\mathrm{NO}_{3}\right)_{2}$ in combination with the same concentrations of $\mathrm{Ca}\left(\mathrm{NO}_{3}\right)_{2}$ as were employed in the two series

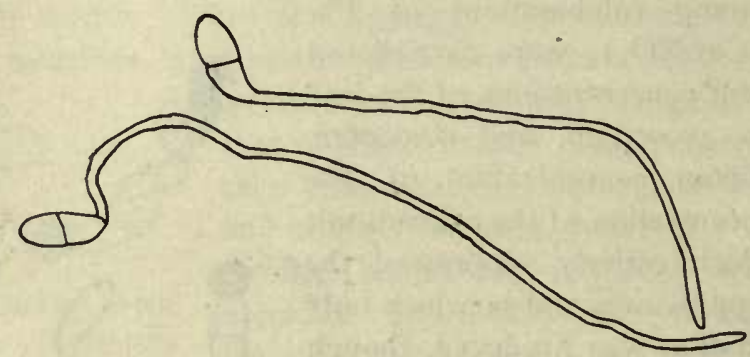

Fig. 5. Germinating spores from combination solution containing $0.00033 \mathrm{~m} \mathrm{~Pb}\left(\mathrm{NO}_{3}\right)_{2}$ and $0.05 \mathrm{~m}$ $\mathrm{Ca}\left(\mathrm{NO}_{3}\right)_{2} \times 650$.

above described, the concentration of the calcium salt in which the majority of the germinating spores formed normal tubes (instead of swellings and appressoria), and the concentration in which only an occasional spore formed a normal germ-tube, were somewhat lower than in the previous series, as was to be expected. The combination containing a $0.002 \mathrm{~m}$ concentration of $\mathrm{Ca}\left(\mathrm{NO}_{3}\right)_{2}$ gave practically the same effect as did the concentration of $0.00004 \mathrm{~m}$ of the lead salt alone, while that containing a $0.00 \mathrm{Im}$ concentration of $\mathrm{Ca}\left(\mathrm{NO}_{3}\right)_{2}$ gave results similar to those obtained with a $0.00002 \mathrm{~m}$ concentration of the lead salt alone. Combinations containing $\mathrm{Ca}\left(\mathrm{NO}_{8}\right)_{2}$ in concentrations of $0.0333 \mathrm{~m}, 0,04 \mathrm{~m}$ and $0.05 \mathrm{~m}$, respectively, produced the same sort of germination as was obtained with a concentration of $0.00033 \mathrm{~m} \mathrm{~Pb}\left(\mathrm{NO}_{3}\right)_{2}$ combined with a $0.05 \mathrm{~m}$ concentration of the calcium salt ; germination was practically all normal, only an occasional appressorium or swelling being found.

From the above data the conclusion seems warranted that the same molecular ratio of the calcium salt to that of lead produces practically 
identical effects with the three different concentrations of $\mathrm{Pb}\left(\mathrm{NO}_{3}\right)_{2}$ here used. Concentrations of $0.01 \mathrm{~m}, 0.02 \mathrm{~m}$ and $0.06 \mathrm{~m} \mathrm{Ca}\left(\mathrm{NO}_{3}\right)_{2}$ combined, respectively, with concentrations of $0.00016 \mathrm{~m}, 0.00033 \mathrm{~m}$ and $0.00066 \mathrm{~m}$ $\mathrm{Pb}\left(\mathrm{NO}_{3}\right)_{2}$ produce practically the same effect on spore germination as does the $0.00005 \mathrm{~m}$ concentration of the lead salt alone. It thus appears that for all three very different concentrations of $\mathrm{Pb}\left(\mathrm{NO}_{3}\right)_{2}$, the addition of $\mathrm{Ca}\left(\mathrm{NO}_{3}\right)_{2}$ in the proportion of six molecules of the calcium salt to one molecule of $\mathrm{Pb}\left(\mathrm{NO}_{3}\right)_{2}$ reduces the toxicity of the latter salt to a point where it almost, but not quite, inhibits normal germination and nearly restricts germinal activity to the formation of appressoria and other swellings. To obtain this same condition of germination a simple solution of $\mathrm{Pb}\left(\mathrm{NO}_{3}\right)_{2}$ must have a concentration of $0.00005 \mathrm{~m}$.

A similar series of equivalent effects upon spore germination, with the three different concentrations of the lead salt, is shown by taking as the index of physiological activity the prevalence of normal germ tubes in the cultures, as contrasted with swellings and appressoria. This condition of affairs is attained in combination solutions containing, respectively, 0.02m $\mathrm{Ca}\left(\mathrm{NO}_{3}\right)_{2}$ combined with $0.00066 \mathrm{~m} \mathrm{~Pb}\left(\mathrm{NO}_{3}\right)_{2}$, o.oIm $\mathrm{Ca}\left(\mathrm{NO}_{3}\right)_{2}$ combined with $0.00033 \mathrm{~m} \mathrm{~Pb}\left(\mathrm{NO}_{3}\right)_{2}$, and $0.005 \mathrm{~m}\left(\mathrm{Ca}\left(\mathrm{NO}_{3}\right)_{2}\right.$ combined with $0.00016 \mathrm{~m} \mathrm{~Pb}\left(\mathrm{NO}_{3}\right)_{2}$. These three combinations of the two salts all produce practically the same effect on germination as does the concentration of $0.00004 \mathrm{~m} \mathrm{~Pb}\left(\mathrm{NO}_{3}\right)_{2}$ alone. Here the addition of about 30 molecules of $\mathrm{Ca}\left(\mathrm{NO}_{3}\right)_{2}$ to $\mathrm{I}$ of $\mathrm{Pb}\left(\mathrm{NO}_{3}\right)_{2}(3 \mathrm{O}: \mathrm{I})$ reduces the toxicity of the lead salt until it is physiologically equivalent to that of the $0.00004 \mathrm{~m}$ solution of this salt alone.

Combination of $\mathrm{Pb}\left(\mathrm{NO}_{3}\right)_{2}$ with $\mathrm{Mg}\left(\mathrm{NO}_{3}\right)_{2}$ shows a similar influence of the alkaline earth upon the toxicity of the heavy metal, though with somewhat different concentrations. Equivalent physiological effects were produced by $0.00066 \mathrm{~m} \mathrm{~Pb}\left(\mathrm{NO}_{3}\right)_{2}$ in combination with $0.02 \mathrm{~m} \mathrm{Mg}\left(\mathrm{NO}_{3}\right)_{2}$, by $0.00033 \mathrm{~m} \mathrm{~Pb}\left(\mathrm{NO}_{3}\right)_{2}$ in combination with o.orm $\mathrm{Mg}\left(\mathrm{NO}_{3}\right)_{2}$ and by $0.00005 \mathrm{~m} \mathrm{~Pb}\left(\mathrm{NO}_{3}\right)_{2}$ alone. Here the addition of about 30 molecules of $\mathrm{Mg}\left(\mathrm{NO}_{3}\right)_{2}$ for each molecule of $\mathrm{Pb}\left(\mathrm{NO}_{3}\right)_{2}$ in the solution, reduced the toxicity of the latter salt so that it became equivalent, in both combinations, to a simple solution containing $0.00005 \mathrm{~m} \mathrm{~Pb}\left(\mathrm{NO}_{3}\right)_{2}$. Under these conditions most of the germinal activity took the form of the production of appressoria and other swellings, but a small amount of normal germination was observed in all cases. Thus, $\mathrm{Mg}\left(\mathrm{NO}_{3}\right)_{2}$ appears to be only about one fifth as effective in reducing the toxicity of the lead salt as is $\mathrm{Ca}\left(\mathrm{NO}_{3}\right)_{2}$.

Magnesium nitrate was not employed in concentration sufficiently high to inhibit all toxic effects of the lead salt. The nearest approach to normal germination was obtained in a combination solution containing $0.05 \mathrm{~m}$ $\mathrm{Mg}\left(\mathrm{NO}_{3}\right)_{2}$ and $0.00033 \mathrm{~m} \mathrm{~Pb}\left(\mathrm{NO}_{3}\right)_{2}$, in which about half of the germina- 
tion was normal. The main points brought out by these experiments are summarized in table II.

TABLE II

\begin{tabular}{|c|c|c|c|c|c|}
\hline Trne of grmination & \multicolumn{4}{|c|}{$\begin{array}{l}\text { Physiologically equivalent solutions containing } \\
\mathrm{Pb}\left(\mathrm{NO}_{3}\right)_{2} \text { alone and in combination with } \\
\mathrm{Ca}\left(\mathrm{NO}_{3}\right)_{2} \text { or with } \mathrm{Mg}\left(\mathrm{NO}_{3}\right)_{2} \text {, molecular }\end{array}$} & \multirow{3}{*}{$\begin{array}{l}\text { Molecular } \\
\text { ratio in } \\
\text { combination } \\
\mathrm{Ca}: \mathrm{Pb} \text { or } \\
\mathrm{Mg}: \mathrm{Pb}\end{array}$} \\
\hline & \multirow{2}{*}{$\begin{array}{c}\text { Simple } \\
\text { solutions, } \\
\mathrm{Pb}\left(\mathrm{NO}_{3}\right)_{2}\end{array}$} & \multicolumn{3}{|c|}{ Combination solutions containing } & \\
\hline & & $\mathrm{Pb}\left(\mathrm{NO}_{3}\right)_{2}$ & $\mathrm{Ca}\left(\mathrm{NO}_{3}\right)_{2}$ & $\mathrm{Mg}\left(\mathrm{NO}_{3}\right)_{2}$ & \\
\hline $\begin{array}{l}\text { Mainly normal. Some appres- } \\
\text { soria and other swellings. }\end{array}$ & 0.00004 & $\begin{array}{l}0.00016 \\
0.00033 \\
0.00066\end{array}$ & $\begin{array}{l}0.005 \\
0.01 \\
0.02\end{array}$ & $\begin{array}{l}\cdots \\
\cdots \\
\cdots\end{array}$ & $\begin{array}{l}30: 1 \\
30: 1 \\
30: 1\end{array}$ \\
\hline $\begin{array}{l}\text { Almost no normal germina- } \\
\text { tion, mainly appressoria } \\
\text { and other swellings....... }\end{array}$ & 0.00005 & $\begin{array}{l}0.00016 \\
0.00033 \\
0.00033 \\
0.00066 \\
0.00066\end{array}$ & $\begin{array}{l}0.01 \\
0.02 \\
\cdots \\
0.06 \\
\cdots\end{array}$ & $\begin{array}{l}\cdots \\
\cdots \\
0.01 \\
\cdots \\
0.02\end{array}$ & $\begin{aligned} 6 & : 1 \\
6 & : 1 \\
30 & : 1 \\
6 & : 1 \\
30 & : 1\end{aligned}$ \\
\hline
\end{tabular}

From the results obtained with the different combinations of calcium and magnesium nitrates with $\mathrm{Pb}\left(\mathrm{NO}_{3}\right)_{2}$, it is evident that the decrease in toxicity of $\mathrm{Pb}\left(\mathrm{NO}_{3}\right)_{2}$, due to the other salt, cannot be caused by a depression of the ionization of the lead salt on account of the common anion. In the combination containing $0.004 \mathrm{~m} \mathrm{Ca}\left(\mathrm{NO}_{3}\right)_{2}$ and $0.00066 \mathrm{~m} \mathrm{~Pb}\left(\mathrm{NO}_{3}\right)_{2}$, about 90 per cent. of the lead salt was calculated to be in the dissociated condition. In the combination containing $0.02 \mathrm{~m} \mathrm{Ca}\left(\mathrm{NO}_{3}\right)_{2}$ or $\mathrm{Mg}\left(\mathrm{NO}_{3}\right)_{2}$ together with a $0.00066 \mathrm{~m}$ concentration of the lead salt, the latter should be about 40 per cent. dissociated. The presence of either of these concentrations of dissociated lead salt alone in a culture solution would either prevent germination entirely or give only abnormal growth. That the decrease in toxicity may have been due to the formation of a double salt remains possible; at least no direct evidence to the contrary was obtained.

With the concentrations of $\mathrm{Pb}\left(\mathrm{NO}_{3}\right)_{2}$ that inhibited germination no granular appearance of the protoplasm, such as was found in otherwise physiologically similar solutions of $\mathrm{Cu}\left(\mathrm{NO}_{3}\right)_{2}$, was evident. Yet it is clear that the lead salt either directly or indirectly affects the protoplasm through the spore wall, as is shown by the formation of the dark bodies occupying one half of the spore in many cases. This response was observed, as has been mentioned, in the higher concentrations of the lead salt. A general discussion of the different forms of germination will be taken up below, after the effects of the combinations of calcium and magnesium nitrates with the other salts have been presented. 
Zinc.

Zinc nitrate, alone and in combination with the nitrates of calcium and magnesium, was studied in much the same way as were the nitrates of copper and lead. Zinc nitrate alone inhibited germination in $0.25 \mathrm{~m}$ concentration. Many local swellings of the spore walls were found in concentrations of $0.08 \mathrm{~m}$ and $0.04 \mathrm{~m}$, while local swellings and short tubes were present in concentrations of $0.008 \mathrm{~m}$ and $0.004 \mathrm{~m}$. Normal germination occurred with the concentration of $0.002 \mathrm{~m}$. Combinations of $\mathrm{Zn}\left(\mathrm{NO}_{3}\right)_{2}$ with $\mathrm{Ca}\left(\mathrm{NO}_{3}\right)_{2}$ and $\mathrm{Mg}\left(\mathrm{NO}_{3}\right)_{2}$ were tested, using a concentration of $0.04 \mathrm{~m} \mathrm{Zn}\left(\mathrm{NO}_{3}\right)_{2}$. In these combinations the calcium salt was employed in concentrations ranging from $0.000125 \mathrm{~m}$ to $0.02 \mathrm{~m}$. Some normal germination occurred with all concentrations of $\mathrm{Ca}\left(\mathrm{NO}_{3}\right)_{2}$ below and including that of $0.0005 \mathrm{~m}$, but none was observed in the mixture containing a $0.000125 \mathrm{~m}$ concentration of this salt. It thus appears that, normal germination of these spores may be brought about in a $0.04 \mathrm{~m} \mathrm{Zn}\left(\mathrm{NO}_{3}\right)_{2}$ solution, by the addition of $\mathrm{Ca}\left(\mathrm{NO}_{3}\right)_{2}$ in the proportion of one molecule of this to every 80 molecules of $\mathrm{Zn}\left(\mathrm{NO}_{3}\right)_{2}$ present.

The concentrations of $\mathrm{Mg}\left(\mathrm{NO}_{3}\right)_{2}$ which were employed in these combinations with the $0.04 \mathrm{~m}$ solution of $\mathrm{Zn}\left(\mathrm{NO}_{3}\right)_{2}$ ranged from $0.00025 \mathrm{~m}$ to $0.025 \mathrm{~m}$. Here it was found that no normal germination occurred until the magnesium salt reached a concentration in the mixture of $0.0025 \mathrm{~m}$. This means that to produce any normal germination in the $\mathrm{Zn}\left(\mathrm{NO}_{3}\right)_{2}$ solution here used, by addition thereto of $\operatorname{Mg}\left(\mathrm{NO}_{3}\right)_{2}$, it is necessary to add one molecule of the latter salt for every 16 molecules of $\mathrm{Zn}\left(\mathrm{NO}_{3}\right)_{2}$ already present. It therefore requires five times as much of the magnesium salt to counteract the toxic influence of $\mathrm{Zn}\left(\mathrm{NO}_{3}\right)_{2}$ in the concentration here used $(0.04 \mathrm{~m})$ as is required of the calcium salt to produce the same effect.

The relatively small amounts of the calcium and magnesium salts, which are required to inhibit the toxic effects of $\mathrm{Zn}\left(\mathrm{NO}_{3}\right)_{2}$ in $0.04 \mathrm{~m}$ concentration, preclude any possibility that the antagonistic influence of either of the former salts might be related to decreased dissociation of the zinc salt, brought about by their addition, so that this consideration needs no attention in this case.

It is interesting to recall here that the effectiveness of $\mathrm{Mg}\left(\mathrm{NO}_{3}\right)_{2}$ in counteracting the toxicity of $\mathrm{Pb}\left(\mathrm{NO}_{3}\right)_{2}$, in the two concentrations studied, so as to allow some normal germination of the spores, was also found to be only about one fifth as great as that of $\mathrm{Ca}\left(\mathrm{NO}_{3}\right)_{2}$. The relative effectiveness of the nitrates of calcium and magnesium thus seems to be the same whether they are employed to counteract the toxicity of $\mathrm{Pb}\left(\mathrm{NO}_{3}\right)_{2}$ or that of $\mathrm{Zn}\left(\mathrm{NO}_{3}\right)_{2}$.

Zinc nitrate did not seem to stimulate the spores to form appressoria, though hyaline swellings were common in the more concentrated solutions. 
No direct evidence was obtained as to whether or not zinc nitrate enters the spores.

\section{Aluminum.}

Aluminum nitrate was used at certain concentrations, both alone and in combination with magnesium and calcium nitrates. Series were carried out, and several times repeated, including the combinations and concentrations which are presented in table III.

\section{TABLE III}

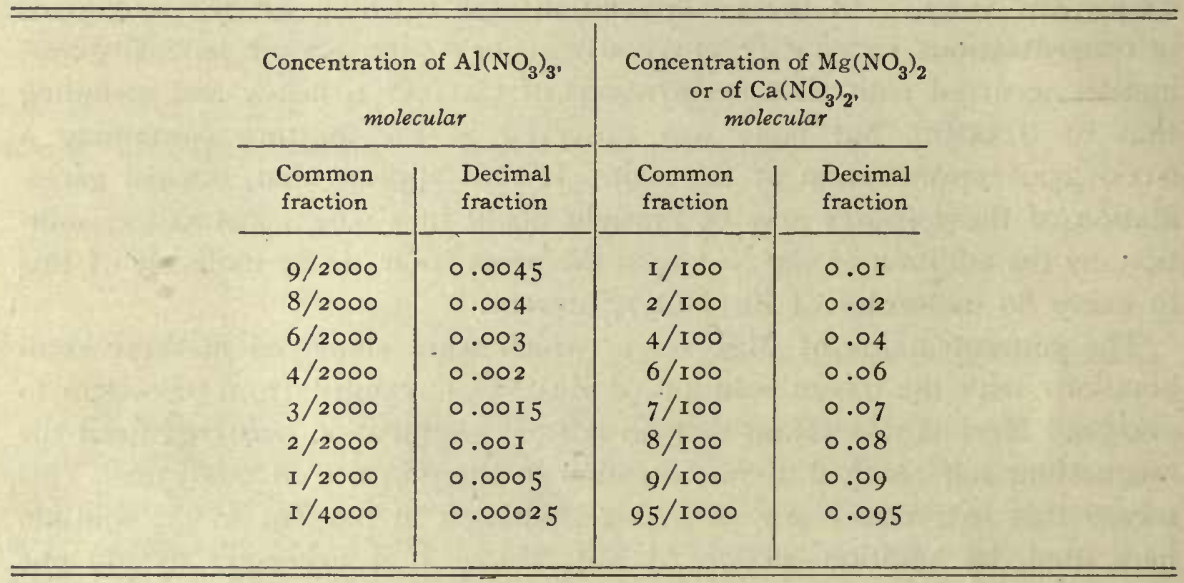

In none of the cultures with $\mathrm{Al}\left(\mathrm{NO}_{3}\right)_{3}$ did the addition of either $\mathrm{Mg}\left(\mathrm{NO}_{3}\right)_{2}$ or $\mathrm{Ca}\left(\mathrm{NO}_{3}\right)_{2}$ bring about any alteration at all in the behavior of the spores. Although many other proportions of these pairs of salts might have been tried, it appears probable that, if either the calcium or magnesium salt, at any concentration, exerts any influence upon the toxicity of $\mathrm{Al}\left(\mathrm{NO}_{3}\right)_{3}$, in any concentration, some evidence in this direction would have been obtained from the experiments which were carried out. This seems still more probable from the fact that different concentrations of the aluminum salt alone produced markedly different effects upon the activities of the spores, a matter which will now receive attention.

In the highest concentration of $\mathrm{Al}\left(\mathrm{NO}_{3}\right)_{3}$ used in the combinations, namely $0.0045 \mathrm{~m}$, only a few local swellings of the spores were observed. A blackening of half of the spore was frequently found here (fig. 6). No normal germination occurred in this solution. In the two lowest concentrations of $\mathrm{Al}\left(\mathrm{NO}_{3}\right)_{3}(0.005 \mathrm{~m}$ and $0.00025 \mathrm{~m})$ however, much of the germination was normal. Aluminum nitrate appears to influence the form of germination occurring in these spores, with much the same results as have been described for cultures poisoned with $\mathrm{Pb}\left(\mathrm{NO}_{3}\right)_{2}$. The types of renewed 
activity which occur with $\mathrm{Al}\left(\mathrm{NO}_{3}\right)_{3}$ are: (I) the formation of a dark body occupying about half of the spore, (2) the formation of a small local swelling at one end of the spore, and (3) the development of one or more appressoria, the latter sometimes having their characteristic dark color and sometimes being hyaline. Unless the formation of the internal dark bodies, which seem to arise directly through protoplasmic activity, may be taken as evidence of a penetration of the toxic salt, no information as to whether $\mathrm{Al}\left(\mathrm{NO}_{3}\right)_{3}$ actually enters the spores was obtained.

\section{Nickel.}

Nickel nitrate proved to be very slightly toxic to these fungus spores, its effect on germination being manifest only in very high concentrations. On this account no study was made of the possible influence of calcium and magnesium nitrates upon this toxicity.

The toxic effects of $\mathrm{Ni}\left(\mathrm{NO}_{3}\right)_{2}$ alone may be added here. A concentration of $0.5 \mathrm{~m}$ inhibited germination. In a concentration of $0.25 \mathrm{~m}$, numerous local swellings of the spores were observed. Both local swellings and normal germination were present in a $0.125 \mathrm{~m}$ solution of this salt, and germination was perfectly normal, as in the distilled water control, where

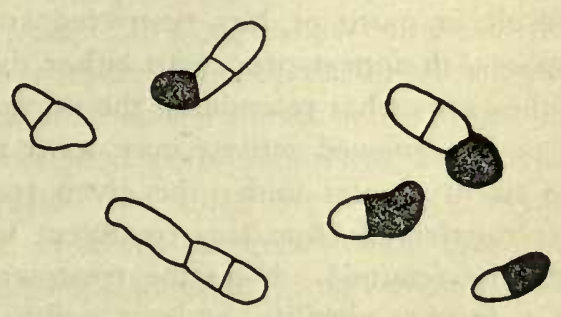

Fig. 6. Germinating spores from $0.002 \mathrm{~m} \mathrm{Al}\left(\mathrm{NO}_{3}\right)_{3}, \times 65^{\circ}$.

a concentration of $0.05 \mathrm{~m}$ or lower was employed. Germinating spores in $0.25 \mathrm{~m}$ concentration of $\mathrm{Ni}\left(\mathrm{NO}_{3}\right)_{2}$ frequently exhibited a granular appearance such as has been described for spores in solutions of $\mathrm{Cu}\left(\mathrm{NO}_{3}\right)_{2}$ which were not quite concentrated enough to inhibit all activity.

\section{TOXICITY OF SINGLE SALTS}

The present section will be devoted to the relative degrees of toxicity exhibited by the various substances heretofore dealt with, together with certain other considerations bearing upon the problem of chemical stimulation as evidenced in the simple solutions employed in these studies. Besides the substances already mentioned, nitric acid entered into the experimentation, and the information gained regarding the toxicity of this substance will also find place here.

From what has preceded it appears possible to group the effects of the different treatments into four distinct kinds of physiological response on the part of the fungus spores here employed. (I) a given treatment may 
be without apparent effect; under such treatments the spores germinate normally within eighteen hours, just as they do in the control with distilled water. (2) Germinal activity may be manifest, but in other ways than that which is here considered as normal. Under treatments which produce this sort of response, the activities of the spores result sometimes (a) in an actual decrease in the exposed surface as well as in the volume of the organism, and sometimes (b) in an increase in both volume and surface, the latter, however, increasing much less markedly,-as related to increase in volume, - than is the case in normal germination. In the first category ( $\mathrm{a}$, above) belong the phenomena involved in the production of the dark bodies which have been described as forming within the spore wall and occupying only a portion of its volume. These appear to have essentially the characteristics of chlamydospores formed within the organism. All other renewed activities of the spores which have been described belong to the second category (b), and embrace those growth processes which result in more or less restricted swellings, especially at the ends of the spores, in appressoria, with either dark or hyaline wall, and in short germ tubes somewhat resembling the normal tubes but of much greater diameter. (3) No renewed activity may occur at all during a period of from eighteen to twenty hours under the given treatment, although ability to germinate if transferred from this treatment to another (as to distilled water) may still be retained. Here the treatment prevents germinal activity but does not destroy viability, at least within the given time limits. (4) Viability, or power to germinate in water, may be destroyed within a period of from eighteen to twenty-four hours; the organism is killed outright.

It has already become clear in this work that most of the substances dealt with produce death within the assumed time limits, if applied at a sufficiently high concentration (4). With a somewhat lower concentration of the injurious material, germination is inhibited but viability is retained throughout the given period (3). When the concentration is still lower germinal activity becomes manifest but takes other forms than those recognized as normal (2). Finally, when the concentration of the toxic agent is still further decreased, the stimulation threshold in the present sense is passed and normal germination becomes the rule (I).

Livingston ${ }^{21}$ working with a green alga has presented a somewhat similar series of responses to chemical stimuli. This writer studied the effect of a large number of nitrates and sulphates on a form of Stigeoclonium, adding different concentrations of the salts to a nutrient medium in which the alga was grown. With a dilute nutrient solution, in which the alga had a characteristic filamentous form, its response to stimulation might be considered as of three types. (I) death, (2) change in phenomena of

\footnotetext{
${ }^{21}$ Livingston, B.E., Chemical stimulation of a green alga. Bull. Torr. Bot. Club 32: 1-34. 1905.
} 
growth, and (3) change in phenomena of reproduction. The response to a high concentration was usually death, while addition of a toxic salt in concentration somewhat below the fatal one stimulated the production of the palmella form, with spherical cells and division occurring in all directions. It is interesting that, with relatively similar concentrations of the salts, (that is at concentrations somewhat lower than those required to inhibit germination) the spores dealt with in the present paper exhibited responses similar to those which Livingston found with his alga; the production of appressoria and swellings in this fungus appears physiologically similar to the production of the palmella form in Stigeoclonium. The third type of response discussed by Livingston, change in phenomena of reproduction, of course finds no parallel in this investigation.

For convenience of comparison, the limits of the various responses of the fungus spores here dealt with, to the different treatments employed, are presented in table IV. The only nitrate occurring in the table that has not already received attention is the acid. In a series of cultures with $\mathrm{HNO}_{3}$ the germination at a $0.005 \mathrm{~m}$ concentration was practically all normal, while at $0.01 \mathrm{~m}$ and all higher concentrations, no germination took place in the eighteen hour period. The acid prevented germination for the period of eighteen hours, in a $0.02 \mathrm{~m}$ concentration and killed the spores in $0.5 \mathrm{~m}$. No concentration was found, therefore, at which the germination took the form of any of the various abnormal growths found at some concentration with all the other substances used, nor was there any apparent coagulation of the protoplasm at concentrations below that which killed the spores. From these considerations it seems, then, that the various abnormal growths and effects on the protoplasm of the spore cannot be due to acid present in the salt solutions, as a result of hydrolysis of the salts, but must be related, either directly or indirectly, to the metals themselves.

Turning now to table $I V$, the different substances are there arranged in the order of the concentration which just allowed normal germination in a period of eighteen hours. In the first column are listed the substances dealt with. The remaining columns are each double. The second column presents the concentrations in which the spores are killed in eighteen hours and fail to germinate later, after transfer to distilled water. Here, as in many other instances, the critical concentrations must not be regarded as definite in the sense of the more exact physical sciences; the concentrations employed in the experimental series were frequently rather widely separated, and, were this not the case, the variability of the organism in its resistance to toxic substances would render quite useless any attempt to define such critical points with very great accuracy. In all such work as the present, dealing with organisms, the internal conditions of the cells must be as important in determining reactions as are the external ones, and we are 


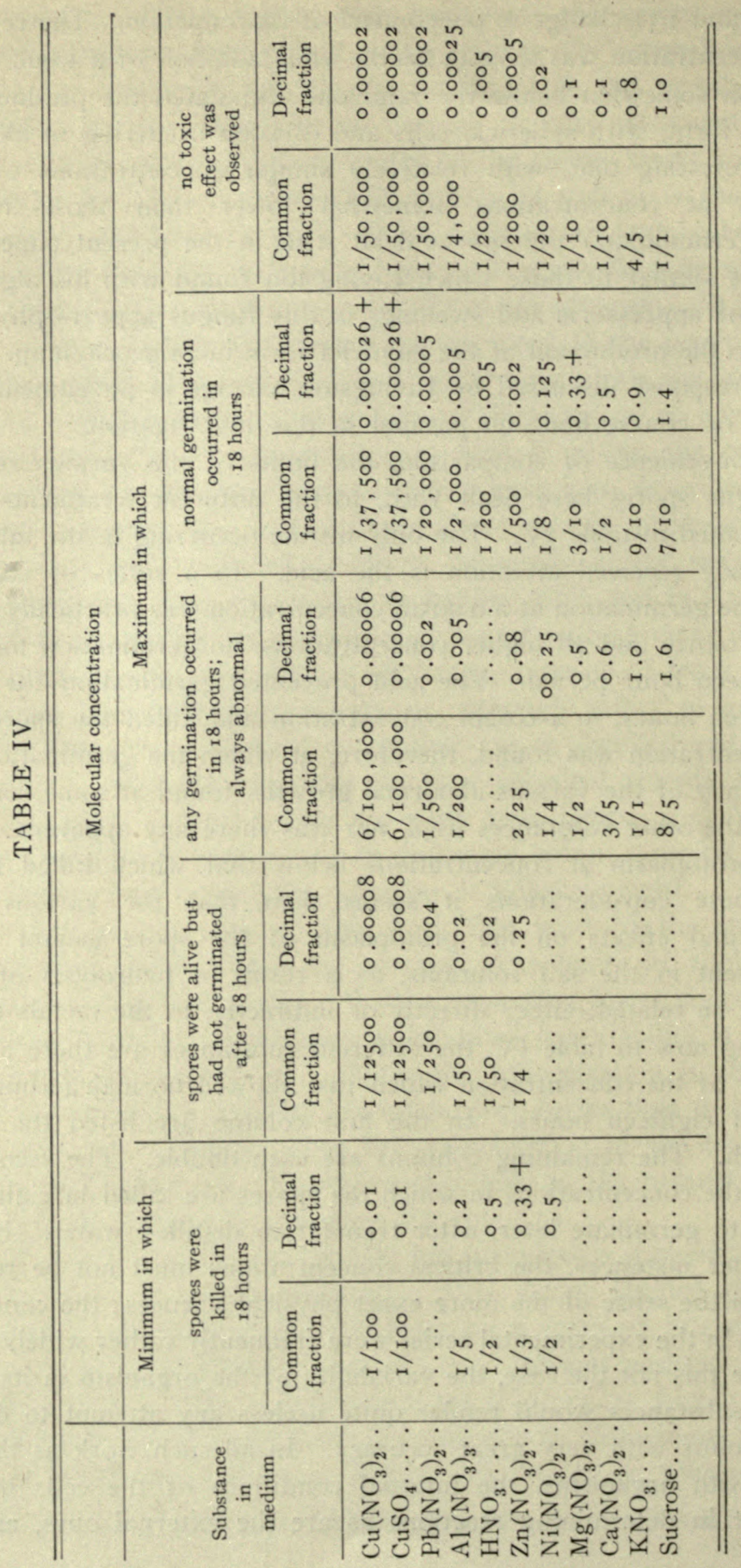


as yet unable either to control or measure the former, excepting in a very general way.

In the third column are found the concentrations at which the different salts inhibit germination for at least eighteen hours. When spores from these cultures were removed from the toxic solution and placed in water for a day, they germinated. The fourth column gives the maximum concentration in which germination occurred. In all cases this growth was abnormal, showing swellings, swollen tubes and other unusual structures, such as are illustrated in figs. I to 6 . In the fifth column the concentrations given are the maxima in which any normal germination was observed. The sixth column presents the highest concentrations in which no toxic influence was manifest.

From table IV it will be seen that the copper salts are by far the most toxic of all the salts here studied. These two salts are very similar in their effect on the germination of the spores, which is in accord with the results of Clark [99], and points almost conclusively to the commonly accepted idea that the toxicity of such copper salts is mainly or entirely due to the copper ion. The last mentioned writer. found that the concentration of copper salts which inhibited germination were higher than those producing the same effect in this investigation, a fact that may probably be due to internal differences in the organisms dealt with; he found that his five fungi varied markedly in their response to the same stimulus. Also, Clark usually made use of nutrient media, while the present studies were carried out without their employment. It is quite possible that the presence of nutrient substances might have modified the effect of the poison. Dug$\operatorname{gar}^{22}$ found the nitrate of copper considerably more toxic than the sulphate and also considerably more so than it is here shown to be. In the work of Stevens, ${ }^{23}$ these two salts affected germination similarly and the concentrations required to prevent germination varied, with the different fungi used, from $\mathrm{m} / 6400$ to $\mathrm{m} / 200$. Many other investigations of the effect of copper on the germination of fungus spores have been carried out, with varying results. The effect of this poison on algae has been studied by Livingston [05]. Kahlenberg and True, ${ }^{24}$, Heald, ${ }^{25}$ Jensen, ${ }^{26}$ Szücs [12] and others, have investigated its toxicity toward higher plants. The results obtained indicate that fungus spores are considerably more resistant toward the toxic effects of copper than are either the algae or higher plants.

\footnotetext{
${ }^{22}$ Duggar, B.M., Physiologicil studies with reference to the germination of certain fungus spores. Bot. Gaz. 31: 38-65. 1901.

${ }^{23}$ Stevens, F.L., The effect of aqueous solutions upon fungus spores. Bot. Gaz. 26: 377-406. 1898 .

${ }^{24}$ Kahlenberg, Louis, and True, Rodney H., On the toxic action of dissolved salts and their elec. trolytic dissociation. Bot. Gaz. 22: $81-124$. 1896.

${ }^{25}$ Heald, F.D., The toxic effect of dilute solutions of acids and salts upon plants. Bot. Gaz, 22 : I25-153. 1806 .

${ }_{26}$ Jensen, G.H., Toxic limits and stimulation effects of some salts and poisons on wheat. Bot. Gaz. 43: $11-44.1907$.
} 
In the order of their toxicity, $\mathrm{Pb}\left(\mathrm{NO}_{3}\right)_{2}$ follows the copper salts, though not closely, with $\mathrm{Al}\left(\mathrm{NO}_{3}\right)_{3}$ next. The effects of the last two salts on plants seems to have been studied but little. Livingston [05] employed them, however, and found the same relation to hold true as is here brought out. Also, Jensen [07] found that $\mathrm{Pb}\left(\mathrm{NO}_{3}\right)_{2}$ is somewhat less toxic toward wheat seedlings than is $\mathrm{Cu}\left(\mathrm{NO}_{3}\right)_{2}$. The nitrates of zinc and nickel, which are next in the order of diminishing toxicity, are not exceedingly toxic toward these Gloeosporium spores. It is interesting to note that Clark [99], working with fungi, and Livingston [05], with an alga, found nickel salts to be more strongly toxic than those of zinc, results which are opposite to those obtained in this investigation.

Magnesium, calcium, and potassium nitrates and cane sugar end the list, in the order named. It is noticeable that, with these last four compounds at concentrations just below that required to inhibit germination, growth takes the form of swollen bodies which tend to give a lower value to the ratio of surface to volume of the organism than that resulting from normal germination. This reaction to toxic stimuli, at concentrations just below those required to inhibit growth, occurs commonly with all the salts here used. That it is found with cane sugar, which is usually regarded as non-toxic (see True ${ }^{27}$ ) suggests that such reactions may be brought about by high osmotic pressure as well as by chemical stimulation in the true sense of this term. This suggestion is in accord with the conclusions of Livingston [05], who has shown that his form of Stigeoclonium assumes the palmella form in response either to a chemical stimulus or to one of relatively high osmotic pressure. Whether this effect of sugar, and similar effects produced by high concentrations of calcium, magnesium and potassium nitrates is really due, in the present instances, to osmotic pressure relations, was not determined experimentally; the minuteness of the spores must render experiments involving plasmolysis exceedingly difficult with such organisms as those here employed. It is obvious, however, that the high concentrations of the calcium, magnesium and potassium salts, found necessary to affect germination, must be capable of exerting an extremely high osmotic pressure if the ectoplasm of the spore is not readily permeable to them.

From table IV it may be seen that, with the exception of $\mathrm{HNO}_{3}$, the different compounds arrange themselves in the same order no matter what type of reaction to the chemical stimuli may be taken as criterion. This suggests that the physiological response of death, on the one hand, and the various morphogenic responses considered in this paper, on the other, are ultimately related to the same properties or characteristics of the various

${ }^{27}$ True, Rodney H., The physiological effects of certain plasmolyzing agents. Bot. Gaz. 26: 407* 416. $\quad 1898$. 
stimulating substances which bring them about. Copper is the most toxic metal here dealt with, whether we consider its toxicity as bringing about changes that result in death or as bringing about the less final changes that lead to abnormal growth. In the same way, magnesium, calcium and potassium are the least toxic metals of the list, on whatever physiological criterion we may base our judgment.

\section{GENERAL DISCUSSION AND CONCLUSION.}

The results of the experiments described in the foregoing pages show that, in certain cases at least, the effect of a toxic salt on the germination of the conidia of Glomerella cingulata may be influenced by the addition, to the medium, of calcium, magnesium or potassium nitrate. That this effect is not due to depression of ionization of the toxic salt has been demonstrated. That it cannot be due to the formation of undissociated double salts has been shown for the combination of $\mathrm{Cu}\left(\mathrm{NO}_{3}\right)_{2}$ with $\mathrm{Ca}\left(\mathrm{NO}_{3}\right)_{2}$ and of $\mathrm{Zn}\left(\mathrm{NO}_{3}\right)_{2}$ with calcium or magnesium nitrate. The influence of calcium upon the toxicity of the salts of the heavy metals here employed must then be related to an effect of the $\mathrm{Ca}\left(\mathrm{NO}_{3}\right)_{2}$ on the spore or to an effect on the contained protoplasm, as is made otherwise probable from the fact that copper, lead, aluminum and nickel nitrates sensibly effect the protoplasm in various ways, without producing any apparent changes in the spore wall.

There are, of course, a number of logically possible explanations for the antagonistic actions of salts upon the germination of fungus spores as here recorded, but any such possible hypothesis must necessarily be very complex if it be able to account generally for even the small array of facts so far at our disposal.

Various theories have been suggested from time to time to explain similar salt antagonisms. Loeb ${ }^{28}$ has advanced the theory of ion-proteid formation, suggesting that one or both ions of a salt may combine with proteids of the protoplasm to form ion-proteid compounds. This writer found, for example, that a solution of $\mathrm{NaCl}$ is poisonous unless some calcium and potassium be also present in the medium, in which case the toxicity of $\mathrm{NaCl}$ is greatly decreased or inhibited altogether. He considers that calcium and potassium ions may to some extent take the place of the sodium ion in the ion-proteid compounds above mentioned, and suggests that the organism cannot live without some of these proteid compounds containing calcium and potassium as well as those containing sodium. The work of Osterhout ${ }^{29}$ on balanced solutions supports this theory of Loeb.

\footnotetext{
${ }^{28}$ Loeb, J., On jon-proteid compounds and their rôle in the mechanics of life phenomena. I. The poisonous character of a pure $\mathrm{NaCl}$ solution. Amer. Jour. Physiol. 7: 327-338. I900.

${ }^{29}$ Osterhout. W. J. V. [06], On the importance of physiologically balanced solutions for plants. II. Fresh water and terrestrial plants. Bot. Gaz, 44:259-272. 1907. 
Wo. Ostwald, ${ }^{30}$ from his studies on Gammarus, concludes that the toxicity of a solution is related to the power of the protoplasm to adsorb the dissolved substance, saying “dass eine Lösung um so giftiger ist je stärker sie adsorbiert wird." Morowitz ${ }^{31}$ somewhat similarly considers that the toxic salt is adsorbed by the surface layer of the organism and dittuses thence into the interior, the amount thas entering in a given time being related to the rate of adsorption. He supposes that, if an otherwise indifferent but strongly adsorbed substance be simultaneously present in the medium, the adsorption of the latter decreases the power of the surface layer to adsorb the toxic salt, so that a smaller amount of this enters the cell.

True and Gies [03] also relate these antagonistic effects to protoplasmic properties, and seem to consider the antagonism between copper and calcium to be due to an accelerating effect of calcium acting against a retarding influence exerted by copper. Szücs [12], as has already been' mentioned, likewise supposes the influence of one salt upon the toxicity of another to be due to simultaneous effects of the two salts upon the protoplasm.

Loeb $^{32}$ has rather recently advanced the theory that the influence of one salt on the toxic action of another is due to changes brought about in the outer colloidal membrane of the protoplasm, whereby the latter becomes impermeable to the toxic salt. Osterhout, ${ }^{33}$ working with cut disks of Laminaria and his method of electrical conductivity, also comes to the conclusion that ([I2], page II5) " the antagonistic action of salts is largely or entirely due to the fact that they hinder or prevent one another from entering the protoplasm."

It will be seen that any one of the various hypotheses just reviewed may, with adequate quantitative assumptions, explain the phenomena of antagonism as these are exhibited by any particular pair of concentrations of any particular pair of salts dealt with in the present study. It seems, impossible, however, to formulate a hypothesis, either by means of any of these published suggestions or with any other logical possibilities, which may simultaneously and satisfactorily account for all the cases with which we have to deal. The marked differences, brought out in the present studies, between the behavior of calcium when employed with copper and that of the same element in combination with lead, zinc or aluminum, strongly stuggest the probability that valence alone does not determine the efficiency of one cation in influencing the toxicity of another. It appears that other properties must be taken into account if such differences are to be explained.

\footnotetext{
${ }^{30}$ Ostwald, Wo., Ueber die Beziehungen zwischen Adsorption und Giftigkeit von Salzlösungen für Süsswassertiere (Gammarus). Archiv. Ges. Physiol. 120: 10-30. 1907

${ }^{31}$ Morowitz, Hugo, Ueber Adsorption und Kolloidfảllung. Kolloidchem. Beih. 1: 301-331. 1010.

${ }^{32}$ Loeb, J., The mechanistic conception of life. Chicago. I912. Page 873.

${ }^{33}$ Osterhout, W.J.V., The permeability of protoplasm to ions and the theory of antagonism. Science N.S. 35: 112-115. 1912.

Some quantitative researches on the permeability of plant cells. Plant World $16:$ r20-144. 1913 .
} 
A consideration of the toxicities of the single salts, as brought out in this investigation, also suggests that the influence of each one of these salts upon the protoplasm of the spore is specific. The nitrates of lead and aluminum, in concentrations somewhat below those which inhibit germination, frequently produce within the spore (either directly or indirectly) a dark, chlamydospore-like body. The presence of copper, at a similar concentration as regards toxicity, causes a granular appearance of the protoplasm and much the same effect was observed in concentrations of nickel nitrate not quite strong enough to inhibit germination. Toxic concentrations of zinc nitrate, however, fail to produce any visible alteration in the protoplasm. The effects of the different single salts upon the spores are therefore not at all the same, and it seems at least reasonable to suppose that the requisite antidotes may not be identical and may not be effective in the same manner in all cases. A given substance at a given concentration may inhibit the poisonous effects of one toxic salt and yet have no influence upon the toxicity of another. Thus, neither calcium nor magnesium nitrate exerts any apparent influence upon the toxic effect of aluminum nitrate, but both are markedly effective in counteracting the toxicity of the corresponding salts of zinc and lead.

The conclusion seems unavoidable, therefore, that no simple and broadly general explanation can be applied to these exceedingly various antagonistic actions, and that the explanation of each particular case must involve the chemical characteristics of the salts concerned and the physico-chemical properties of their solutions. The exceeding complexity of the material system within the cell must make possible a great variety of explanations until this variety becomes further limited by increased knowledge. As has been well emphasized by Osterhout [13] the future advance of our knowledge of this intricate subject must depend solely upon further investigation of a quantitative nature.

The Laboratory of Plant Physiology

OF THE JOHNS HopkINS UNIVERSITY.

APRIL I, I9I3.

\section{LITERATURE . CITED.}

Numbers in brackets throughout the preceding pages refer to the year of publication and to the corresponding numbers which follow authors' names in this list.

Acree, S.F. [II]. See Loomis and Acree [II].

Bartlett, H.H. [12]. See True and Bartlett [12].

Clark, J.F. [99], On the toxic effect of deleterious agents on the germination and development of certain filamentous fungi. Bot. Gaz. 28: 280-327, 378-404. 1890 .

[or], On the toxic value of mercuric chloride and its double salts. Jour. Physic. Chem. 5: $289-316$. 1901.

[02], On the toxic properties of some copper compounds wth special reference to Bordeaux mixture. Bot. Gaz. 33: 26-48. 1902. 
Duggar, B.M. [or], Physiological ștudies with reference to the germination of certain fungus spores. Bot. Gaz. 31: 38-65. I901.

Gies, W.J. [03]. See True and Gies [03].

Hasselbring, H. [06], The appressoria of anthracnoses. Bot. Gaz. 42: 135-142. 1906.

Heald, F.D. [06], The toxic effect of dilute solutions of acids and salts upon plants. Bot. Gaz 22: i25-153. 1896 .

Holland, W.A. [०9]. See Morse and Holland [०g].

Hosford, H.H., and Jones, H.C. [11], Conductivity, temperature coefficients of conductivity and dissociation of certain electrolytes. Am. Chem. Jour. 46: 241-278. 1911.

Jensen, G.H. [07], Toxic limits and stimulation effects of some salts and poisons on wheat. Bot. Gaz. 43: 11-44. 1907.

Jones, H.C. [11]. See Hosford and Jones [ir].

[ $\mathrm{r} 2]$, Electrical conductivity, dissociation and temperature coefficients of conductivity, from zero to sixty-five degrees, of aqueous solutions of a number of salts and organic acids. Carnegie Institution of Washington Publ. 170. Washington. I9I 2.

Kahelenberg, L., and True, R.H. [96], On the toxic action of dissolved salts and their electrolytic dissociation. Bot. Gaz. 22: 81-124. 1896 .

Krônig, B., and Paul, Th. [97], Die chemischen Grundlagen der Lehre von der Giftwirkung und Desinfection. Zeitschr. Hygiene und Infectionskrankheiten 25: 1-112. 1897.

Le Renard, A. [12], Influence du milieu sur la résistance du Penicille crustacé aux substances toxiques. Ann. Sci. Nat. Bot. IX. 16: $276-336$. 1912.

Livingston, B.E. [05], Chemical stimulation of a green alga. Bull. Torr. Bot. Club 32: 1-34. 1905 .

Loeb, J. [oo], On ion-proteid compounds and their rôle in the mechanics of life phenomena. I. The poisonous character of a pure $\mathrm{NaCl}$ solution. Amer. Jour. Physiol. 7: 327-338. I900.

[02], Ueber den Einfluss der Werthigkeit, und möglicherweise der electrischen Ladung für Ionen auf ihre antitoxisch Wirkung. Archiv ges. Physiol. 88: 68-78. 1902.

[06], The dynamics of living matter. New York. 1906. [12], The mechanistic conception of life. Chicago. Ig12.

Loew, O. [92], Ueber die physiologischen Functionen der Calcium- und Magnesium-salze im Pflanzenorganismus. Flora 75: 368-394. 1892 .

Loomis, N.E., and Acree, S.F. [ir], A study of the hydrogen electrode, of the calomel electrode and of contact potential. Amer. Chem. Jour, 46:585-620. I911.

Morowitz, H. [10], Ueber Adsorption und Kolloidfällung. Kolloidchem. Beih. 1: $301-331$. 1910.

Morse, H.N., and Holland, W.W. [09], The osmotic pressure of cane sugar solutions at $25^{\circ}$. Amer Chem. Jour. 41: I-19. 1909.

Osterhout, W.J.V. [06], On the importance of physiologically balanced solutions for plants. I. Marine plants. Bot. Gaz. 42: 127-134. 1906.

[07], On the importance of physiologically balanced solutions for plants. II. Fresh water and terrestrial plants. Bot. Gaz. 44: 259-272. 1907.

[12], The permeability of protoplasm to ions and the theory of antagonism. Sci. N.S. 35: $112-115.1912$.

[13], Some quantitative researches on the permeability of plant cells. Plant World 16: 129-144. 1913.

Ostwald, Wo. [07], Ueber die Beziehungen zwischen Adsorption und Giftigkeit von Salzlōsungen für Süsswassertiere (Gammarus). Archiv. ges. Physiol. 120: 19-30. 1907.

Paul, Th. [97]. See Krönig and Paul [97].

Shear, C.L., and Wood, Anna K. [13], Studies of fungus parasites belonging to the genus Glomerella. U.S. Dept. Agric. Bur. Plant Ind. Bulletin 252. 1913.

Stevens, F.L. [98], The effect of aqueous solutions upon fungus spores, Bot. Gaz. 26: 377-406. 1898 .

Szūcs, J. [12], Experimentelle Beiträge zu einer Theorie der antagonistischen Ionenwirkungen. Jahrb. wiss. Bot. 52: 85-143. I91 2 .

True, R.H. [96]. See Kahlenberg and True [96].

[98], The physiological effects of certain plasmolyzing agents. Bot. Gaz. 26: 407-416. 1898 .

True, R.H., and Bartlett, H.H. [1 2], Absorption and excretion of salts as influenced by concentration and composition of culture solutions. U.S. Dept. Agric. Bur. Plant Ind. Bulletin 231. I912.

True, R.H., and Gies, W.J. [03], On the physiological action of some of the heavy metals in mixed solutions. Bull. Torr. Bot. Club 30: 390-402.1903.

Wood, Anna K. [13]. See Shear and Wood [13] 


\section{VITA.}

The writer was born at La Motte, Iowa, May 30, I880. He attended Morningside Academy and College, Sioux City, Iowa, and was graduated with the degree of Bachelor of Science in 1906. The summer of 1904 was spent in special work in Botany at the University of Chicago. From I903 to 1906 he was assistant at Morningside College, Fellow in Botany at the Ohio State University September 1906 to April 1907, and Scientific Assistant, United States Department of Agriculture, April Igo7 to the present (on furlough October I9I2 to June I9I3). During the years from I909 to I9I3 he attended the Johns Hopkins University as a graduate student in Plant Physiology, Chemistry, and Botany, and was appointed University scholar in Plant Physiology for the year I9r2-I9I3. 



U.C. BERKELEY LIBRARIES

||

соз972звьь

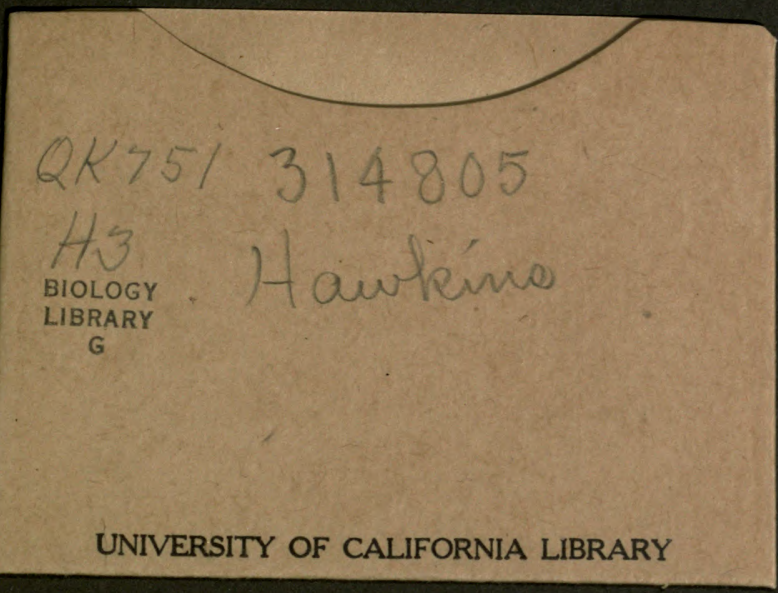


